Portland State University

PDXScholar

1987

\title{
Liking and disliking to be touched by staff as reported by female nursing and retirement home residents
}

Mary Beth Pintarich

Portland State University

Follow this and additional works at: https://pdxscholar.library.pdx.edu/open_access_etds

Part of the Communication Commons, and the Nursing Commons

Let us know how access to this document benefits you.

\section{Recommended Citation}

Pintarich, Mary Beth, "Liking and disliking to be touched by staff as reported by female nursing and retirement home residents" (1987). Dissertations and Theses. Paper 3745.

https://doi.org/10.15760/etd.5629

This Thesis is brought to you for free and open access. It has been accepted for inclusion in Dissertations and Theses by an authorized administrator of PDXScholar. Please contact us if we can make this document more accessible: pdxscholar@pdx.edu. 
AN ABSTRACT OF THE THESIS OF Mary Beth Pintarich for the Master of Science in Speech Communication presented Apri1 8, 1987 .

Title: Liking and Disliking to be Touched by Staff as Reported by Female Nursing and Retirement Home Residents.

APPROVED BY MEMBERS OF THE THESIS COMMITTEE:
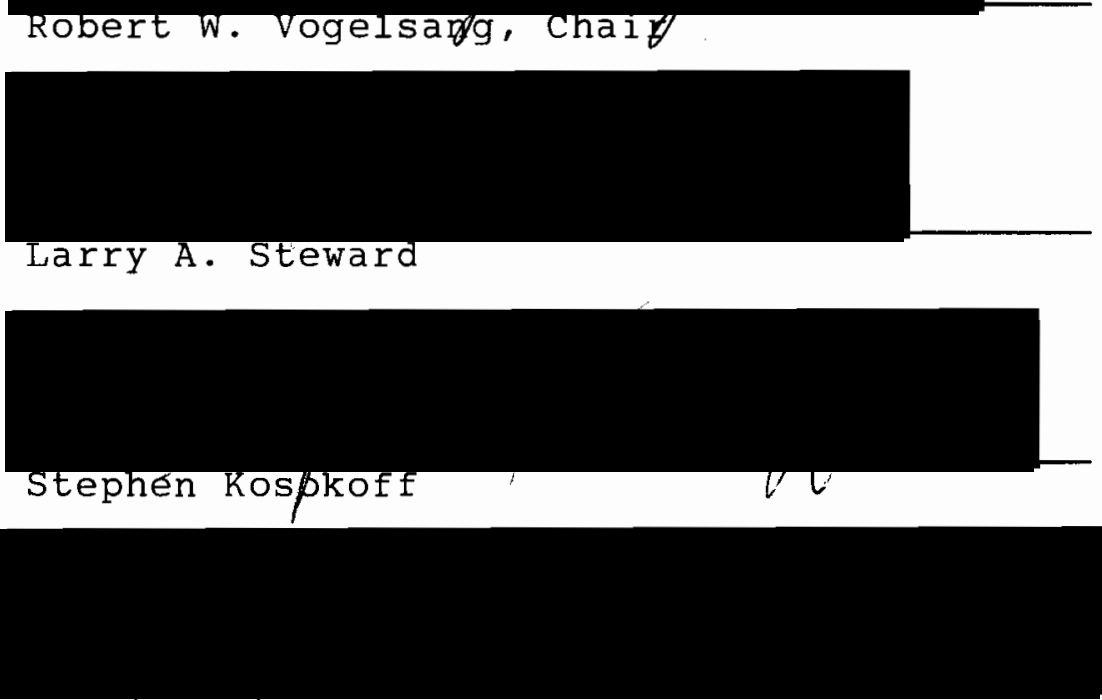

Morris Weitman

Touch--both touching another and being touched--is a primary form of communication. By old age, both the need and the desire for specific amounts and kinds of touching are well established for the individual. The present study was designed to obtain information about what elderly women 
in nursing and retirement homes report to be liked and disliked types of touching. Participants who volunteered for this study were 32 ambulatory females 65 years of age or older who were living in nursing or retirement homes. Each participant was shown a set of 20 photos and sketches depicting a staff person touching an elderly woman in various ways, and asked to rate their liking for the particular type of touching on a one to five scale ranging from "like very much" to "dislike very much." The set of photos and sketches included ten comparable scenes with one-half showing a male staff member and the other half showing a female staff member touching an elderly woman. Scenes included: foot massage, helping to stand, back rub, brushing hair, arm around shoulder, holding hand, helping to dress, stroking cheek, helping with toileting, and helping with a shower.

A rank order comparison of means showed that the most liked type of touch was that of a female staff member giving a foot massage $(\underline{M}=1.63)$, and the least liked type of touch was that of a male staff member helping with toileting $(\underline{M}=4.09)$. A comparison of liking of types of touch related to sex of the staff member showed that for nine of the ten types of touch, participants preferred the female over the male staff member with the exception being helping to stand. For six of the ten types of touch, the difference was statistically significant favoring the female staff member. There were four statistically significant differences in the 
liking of touch between nursing home and retirement home participants. Retirement home participants reported greater liking for foot massage by both female and male staff. Nursing home participants reported less disliking for helping with toileting by male staff. However, for female staff, nursing home participants reported neither liking nor disliking help with toileting. A principal-components factor analysis produced seven factors indicating that the 20 item rating procedure contains seven dimensions. Based on the verimax rotated factor matrix, the factors appeared to be: liked touching by a male, acceptable nonessential touching, disliked touching by a male, intimate touching by a female, acceptable touching by a female, liked nonessential touching, and neutral nonessential touching.

Although female staff are preferred over male staff in all but one type of touching, a majority of the participants liked foot massage, brushing hair, and back rub by both female and male staff. The most disliked types of touching were helping with toileting and helping with a shower. 
LIKING AND DISLIKING TO BE TOUCHED BY STAFF AS REPORTED BY FEMALE NURSING AND RETIREMENT HOME RESIDENTS

$$
\text { by }
$$

MARY BETH PINTARICH

A thesis submitted in partial fulfillment of the requirements for the degree of

\author{
MASTER OF SCIENCE \\ in \\ SPEECH COMMUNICATION
}

Portland State University

1987 
TO THE OFFICE OF GRADUATE STUDIES AND RESEARCH:

The members of the Committee approve the thesis of Mary Beth Pintarich presented Apri1 8, 1987

Robert w. Vogefsang, Chair

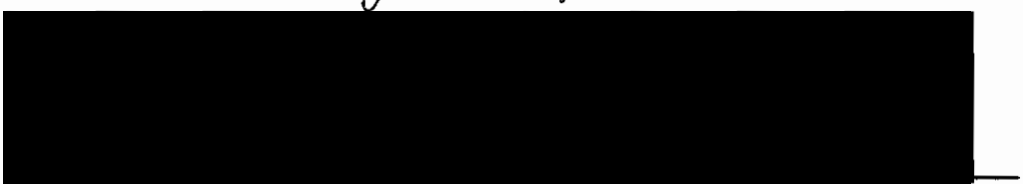

Larry A. Steward
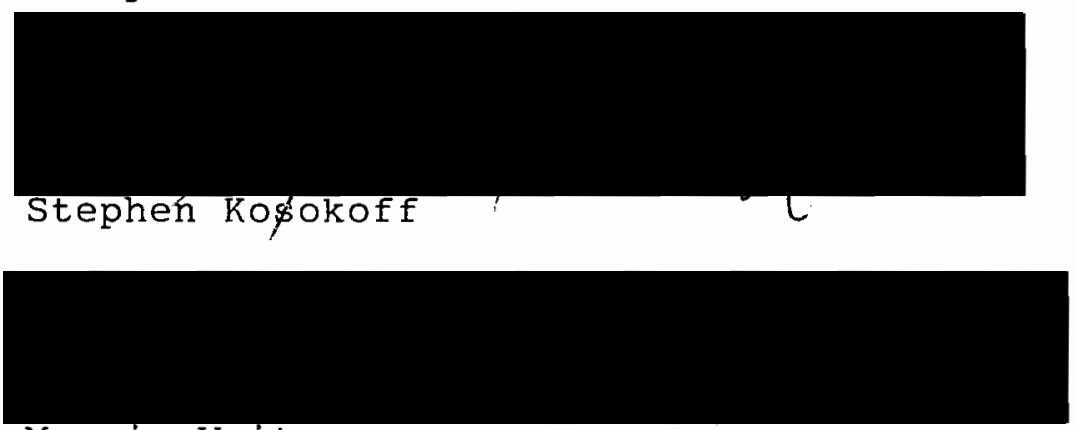

Morris Weitman

APPROVED :

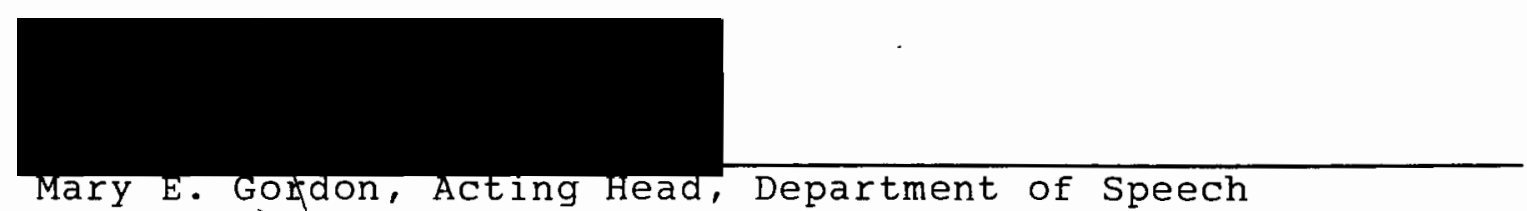

Communication

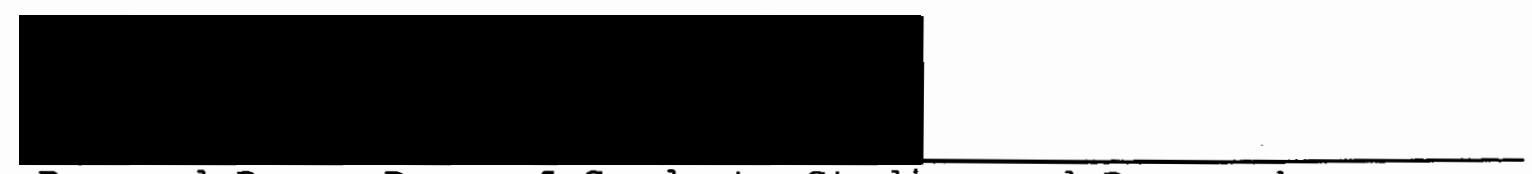

Bernard Ross, Dean of Graduate Studies and Research 


\section{ACKNOWLEDGMEN'TS}

I feel I am privileged to be able to thank so many people for their help and encouragement in completing this thesis. Their help and support makes this project theirs as well as mine.

First, thanks Mom, you know what you did for this project that went beyond the usual moral support you always provide. And Leslie, thinks for helping when I needed it.

Next, I want to extend my thanks and express my appreciation to Robert Vogelsang, my advisor and thesis committee chairman. The idea for my thesis came long ago in a class I took from you, and you have been a constant source of both encouragement and ideas ever since. I also want to thank my other committee members, Steve Kosokoff and Larry steward who provided not only technical advice, but also leads, tips, and contacts. A special thanks goes to Al Sugarman who, although not on my committee, spent much time reading early drafts and giving suggestions.

Several other people contributed, each in their own way. I want to thank Terry Rogers, Shanin Thompson, Joyce Colling, Mark Hammer, Pat and Ron Wise, Karin Wilson, and the artist who drew the sketches, Robert combe. A big thanks goes to Carolyn Charette-Butler and Carol Trumbauer, my interviewers. Your enthusiasm for working on the project, your attention to detail, and your genuine care and concern 
for the participants made me glad to be working with you both. And to the participants who were willing to spend the time answering my questions--thank you.

Last, I want to thank Chad Karr for all the help he gave me. Your constant suggestions of other things to try when I hit dead ends, your help with the statistical procedures, and your never ending, "How's your thesis coming?" kept me working so that I can now say, "It's done." 
TABLE OF CONTENTS

PAGE

ACKNOWLEDGMENTS . . . . . . . . . . . . . . . . .

LIST OF TABLES . . . . . . . . . . . . . . . vii

LIST OF FIGURES . . . . . . . . . . . . . . . viii

CHAPTER

I INTRODUCTION

Review of the Literature ...... . 3

Purpose of the Study . . . . . . . 4

II METHOD . . . . . . . . . . . . . . 6

Subjects . . . . . . . . . . . . 6

Materials . . . . . . . . . . . 7

Procedure . . . . . . . . . . . 10

Training of Interviewers : . . . . . . 11

Reliability . . . . . . . . . 12

Concurrent validity . . . . . . . . 12

III RESULTS . . . . . . . . . . . . . . . . . 14

Demographic Data . . . . . . . . . 14

Rank Order of Liking of Types of Touch . . . . . . . . . . .

Comparison of Liking of Types of Touch

Related to Sex of Staff Member . . . 16

Comparison of Liking of Types of Touch

Related to Place of Residence... . 18

Prediction of Mean Liking by Demographic

Characteristics . . . . . . . . 20 


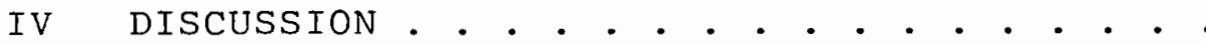

Factor Analysis of Ratings . . . . . . .

Item Analysis by Stepwise Multiple Regression . . . . . . . . . . 24

Construct Validity . • . . . . . . . . 27

Liking and Disliking of Touching . . . . . 27

Logistical Considerations . . . . . . . 29

Implications of this study . . . . . . . 31

REFERENCES

APPENDIX

A Informed Consent . . . . . . . . . . . 34

B Demographic Questionnaire . . . . . . . . 35

C Photos and Sketches, 1-20. . . . . . . . 36

D Rating Card. . . . . . . . . . . . . . 46

E Rating Form . . . . . . . . . . . . . . 47

F Interviewer Instructions . . . . . . . . . . 48

$G$ List of Photos and Sketches in order of Presentation . . . . . . . . . . 50

$\mathrm{H}$ Interviewer Checklist . . . . . . . . . . 51

I Rotated Factor Matrix of Participant's Ratings . . . . . . . . . . . . 52 


\section{LIST OF TABLES}

TABLE

PAGE

I Rank Order of Liking of Types of Touch . . . . . 16

I Liking of Types of Touch Related to Sex of

Staff Member • . . . . . . . . . . . 17

II Liking of Types of Touch Related to Place

of Residence • . • . . . . . . . . . . . . 19

IV Item Analysis of Stepwise Multiple Regression . 26

V Rotated Factor Matrix of Participant's

Ratings . . . . . . . . . . . . . . 


\section{LIST OF FIGURES}

FIGURE

PAGE

1. Male Staff--Giving Foot Massage . . . . . . . 36

2. Female Staff--Giving Foot Massage . . . . . . 36

3. Male Staff--Helping to Stand . . . . . . . . 37

4. Female Staff--Helping to Stand . . . . . . . 37

5. Male Staff--Giving Back Rub . . . . . . . . 38

6. Female Staff--Giving Back Rub . . . . . . . 38

7. Male Staff--Brushing Hair . . . . . . . . . 39

8. Female Staff--Brushing Hair . . . . . . . . 39

9. Male Staff--Arm Around Shoulder . . . . . . . 40

10. Female Staff--Arm Around Shoulder . . . . . . 40

11. Male Staff--Holding Hand . . . . . . . . . 41

12. Female Staff--Holding Hand . . . . . . . . . 41

13. Male Staff--Helping to Dress . . . . . . . 42

14. Female Staff--Helping to Dress . . . . . . . 42

15. Male Staff--Stroking Cheek . . . . . . . . 43

16. Female Staff--Stroking Cheek . . . . . . . . 43

17. Female Staff--Assisting with Toileting . . . . 44

18. Male Staff--Assisting with Toileting . . . . . 44

19. Female Staff--Helping with Shower . . . . . . 45

20. Male Staff--Helping with Shower . . . . . . 45 


\section{CHAPTER I}

\section{INTRODUCTION}

Research on touch deprivation in infants and children has been extensive and has shown that both psychological and physical illness can result from lack of physical contact. Eczema (Rosenthal, 1952), behavioral disorders and schizophrenia (Lowen, 1969), and 100 percent infant mortality for institutionalized infants under two years of age (Chapin, 1915) are three examples of effects associated with touch deprivation. Rheingold (1956) showed that institutionalized infants given extra "nurturance" displayed more social responsiveness than those getting routine care. Many elderly individuals in retirement and nursing homes appear to have symptoms similar to touch-deprived infants and children. Several studies have been conducted focusing on how touching is perceived by elderly patients and how touching is utilized by health personnel. Hollinger (1980) summarized the results of studies on perception by stating that, in general, all studies report an interrelationship among environmental, cultural, and social factors in terms of their influence upon the perception of touch (p. 742). McCorkle (1974) found that patients often feel alone during a serious illness and interpret the 
touching of nurses as a sign of caring. In a study of patients who were bedridden for a lengthy period of time, Miller (1975) found that prolonged bedrest resulted in a general decrease of sensory information which affected perceptual input; he noted several behavioral changes including "increased anxiety and dependency, increasing aggressive and hostile behavior, increasing placidity on the part of others, and increasing sexual tension and discomfort" (p. 367). In a general hospital setting, Barnett(1972) found that patients over 66 years of age received the least frequent amount of touch of any age group. She also noted that race, sex, and age of both the caregiver and the patient as well as the seriousness of the patient's condition were variables which affected the amount of touch given by some caretakers and received by some patients. Caucasian female caregivers between the ages of 18 and 25 touched their patients more than any other group. Caucasian female patients in general received greater amounts of touching; however, the more serious their condition and the older they were, the less they were touched.

One study reported that some elderly patients perceive touch negatively. dewever (1977) asked subjects to rate seven types of affective touching as either "comfortable" or "uncomfortable." She showed four pictures of nurses (older male, older female, younger male, younger female) one at a time in random order as a verbal description of a 
particular type of touching was read. Subjects were asked for their rating choice. Results showed that while some patients found touching by nurses to be comfort-promoting, other patients perceived the touching as uncomfortable. The difference in perception was attributed in general to the patient's particular socialization, and in particular to the sex of the patient and of the nurse. Female patients responded with discomfort much more often if the nurse was male (p. 168). dewever also found that an arm around the shoulder by either male or female nurses was perceived as uncomfortable by the greatest number of subjects ( $p .169$ ).

\section{REVIEW OF THE LITERATURE}

Although several studies have been conducted which have provided information about how some elderly patients perceive touch and the potential for the importance of touching elderly patients, reported research regarding effects of touch deprivation on elderly individuals is very limited. Extensive library research, including a national computer search, identified only two studies in this area,. one which was specific to an elderly population and in which the investigator increased the amount of touching over and above baseline amounts (Burnside, 1973), and one which provided a baseline for who touches whom and how often in a nursing home (watson, 1975). This latter study noted several things which suggest strong implications for the physical and mental well-being of elderly patients in 
nursing homes. Watson found that patients were touched more by same-sex staff, and that patients who were less impaired (mild depression or physical impairments) were touched more than patients with more serious impairments. Burnside studied geriatric patients diagnosed as having chronic brain syndrome which is a regressed state marked by behaviors such as "babbling, withdrawal, inappropriate replies, hallucinations, exhibitionism, and refusal to make eye contact" (p. 2061). She began her experiment by initiating hand-tohand or hand-to-shoulder contact with the patients. She then noted that patients began touching each other and that appropriate verbal communication and eye contact increased among patients and with staff.

Other studies with adults but not specific to elderly individuals have shown significant changes in patients who are treated with increased amounts of touching by staff. Aguilera (1967) observed that patients, especially those diagnosed as schizophrenic, showed "increased verbal interaction, rapport, and approach behavior" (p. 13) following increased use of touch by the staff. In another study, Krieger (1975) found a statistically significant change in hemoglobin values as a result of therapeutic touch.

PURPOSE OF THE STUDY

Touch--both touching another and being touched--is a primary form of communication which begins the moment a baby is born and which helps the infant define its world and gain 
information about itself (Montague, 1978; Morris, 1971). As the child develops, it learns to give and receive touch based on cultural, social, and individual influences (Hall, 1973). By the time a person reaches old age, both the need for specific amounts and kinds of touching and the desire for specific amounts and kinds of touching are well established for the individual.

Touch as a survival need of infants has been wellestablished. Touch as a survival need for the elderly is intuitively accepted, but experimentally undocumented, and may remain so because there it is extremely difficult to control for the effects of touch alone as a variable when dealing with elderly individuals. Therefore, to determine that touch is a need of the elderly would be to assume that all that is required to extend life for the elderly would be an increase in the amount of touching given to the individual. This proposition would be both simplistic and untestable. What can be established are the possible limits of what elderly individuals like or dislike in the way of being touched.

The purpose of this study was to establish what elderly females in nursing and retirement homes reported to be liked and disliked forms of touching in order to increase the sensitivity of staff to resident needs. Should caring touch be routinely given in retirement and nursing homes as one way of providing quality care? 
CHAPTER II

METHOD

SUBJ ECTS

The participants in this study were 32 females, 12 of whom were in an intermediate care nursing home, and 20 of whom were in two retirement homes in the Portland metropolitan area. Criteria for selection of homes included the serving of one or more meals per day and a voluntary daily or weekly program of organized activities. One retirement home was fairly new, having opened approximately five years ago, and the other was an established home which was approximately 30 years old. The first was selected because of its newness and the other was selected because of its proximity to Portland State University. The nursing home was selected because of the willingness of the administration to allow a study to be conducted within the home.

Participants were ambulatory, had a minimum of three months in residence, were 65 years or older, had the ability to participate in group meals and activities, were able to respond with understanding to verbal questions, and were willing to rate their reactions to a set of photos and sketches depicting a staff person touching an elderly woman along with a verbal description of the touching involved. 
All 8 potential participants contacted in one retirement home volunteered for this study, and 12 out of 17 women contacted in the other retirement home agreed to participate. In the nursing home, 12 out of 20 agreed to participate. Those residents who participated in this study were obtained by contacting residents individually.

In all cases, I first secured permission from the administrator of the home to contact residents. I explained the purpose of the study to the administrator and showed the materials to be used. At both retirement homes, the administrator granted permission to contact residents directly.

At the nursing home, the social service director developed a list of potential participants based on the criteria for participation in this study. Before any contact with residents could be made, the home required that I contact the responsible party for the resident and obtain verbal permission to contact the resident. Once this permission was obtained, each interviewer had to initiate her own contact with the individual residents.

\section{MATERIALS}

The materials used in this study included a questionnaire designed to gather demographic data, a set of 20 photos and sketches depicting a staff person touching an elderly woman, a rating card with a verbal description of 5 levels of liking, and a rating form on which the interviewer recorded the participant's ratings. 
Demographic Data Questionnaire

After obtaining informed consent (see Appendix A for a copy of the Informed consent) to participate in this study, the interviewer asked the participant to provide the following demographic information: sex; age; years of education; occupations and years in each; marital status, past and present, and if widowed or divorced, for how long; number and sex of siblings including half and step siblings and whether living or not; number and sex of children including step children and whether living or not (see Appendix $B$ for a copy of the questionnaire).

\section{Photos and Sketches}

I took 28 photos in which a male or a female staff person was shown touching an elderly woman and selected seven pairs of the photos for this study. Each pair showed a male or a female staff person touching a resident in a corresponding manner. I tried to match photos in a pair for a given type of touch according to the greatest similarity between the photos. I looked for such things as similarity of pose and facial expression, and tried to reduce the differences, except for sex of staff, as much as possible. I also commissioned an artist to draw three pairs of sketches illustrating a male or female staff person touching an elderly woman in a similar way. I used sketches to illustrate those scenes which portrayed caretaking which could be described as intimate personal care, but which was realistic in a nursing home setting, since intimate personal 
care could not be photographed. Four of the sketches showed such care. Two sketches showing a noncaregiving touch were used to determine if the participants were responding to the sketches themselves rather than to the touching which was being portrayed. A factor analysis of the ratings seemed to reflect no relationship as to whether the scene was a photograph or a sketch. Each photo and sketch was 4 x 6 inches and each was secured to a 7 x 11 inch piece of posterboard. The verbal description for the scene was printed in large black letters above the picture, and each picture was identified by a large black numeral located under the picture. Scenes were presented in a semi-random way in that none of the intimate caregiving scenes was shown at the start of the sequence. Otherwise, the scenes were randomly mixed and then numbered.

The set included 10 photos and sketches showing a male staff member and 10 photos and sketches showing a female staff member touching the resident in some way. Except for the sex of the staff member, the two halves of the set had corresponding scenes. All scenes portrayed appropriate behavior on the part of the staff member. None portrayed intentionally sexually stimulating behavior. The following scenes were portrayed in photos: the staff member stroking a resident's cheek, working with her.hair, placing an arm around her shoulder, helping her to stand, giving a back rub, assisting her to dress, and giving a foot massage. Those scenes portrayed with sketches were the staff member 
holding a resident's hand, giving a shower, and assisting with toileting (see Appendix $C$ for copies of the photos and sketches).

\section{$\underline{\text { Rating Card }}$}

To provide maximum readability, the rating card used by the subject was an $8-1 / 2 \times 11$ inch card with large letters listing five levels of liking ranging from "Like very much" to "Dislike very much." These levels were numbered one to five (see Appendix D for a reduced copy of the rating card).

\section{Rating Form}

The interviewer's rating form had 20 numbered rows with five columns numbered one through five. Each row corresponded to one of the numbered photos or sketches, and each column corresponded to the level of liking scale (see Appendix E for a copy of the rating form).

\section{PROCEDURE}

After contacting the prospective participant, the interviewer described the study and its purpose and read and explained the form for informed consent. Upon obtaining the participant's signed consent, the interviewer next obtained and recorded answers to the structured demographic interview. Following completion of the demographic interview, the participant was shown the set of 20 photos and sketches in the prescribed order. After viewing each photo or sketch, the 
interviewer asked the participant to rate the degree of liking or disliking for the type of touching depicted in the sketch. The interviewer immediately recorded the participant's rating of each photo or sketch.

When the ratings were completed, the interviewer thanked the subject for her participation. In all cases interviewers visited casually with the participant for a few minutes at the end of the rating session.

\section{TRAINING OF INTERVIEWERS}

Three women conducted the interviews--the researcher and two university students. Both of the students were in their early $30^{\prime}$ s and both were senior psychology majors who were specializing in issues concerning aging. Training consisted of having the two student interviewers become familiar with the criteria for selection of participants, interviewer instructions (see Appendix $F$ for a copy of the instructions), the Informed Consent form, the Demographic Questionnaire, the set of photos and sketches, a list identifying the photos and sketches according to the order or presentation (see Appendix $G$ for a copy of the list), a participant rating card, and the rating form. A check 1 ist itemizing interviewer materials to be used and order of use was included (see Appendix $H$ for a copy of the check list).

Training also included the importance of confidentiality, the purpose of the study, and the need for sensitivity to the personal needs and concerns of each participant. 
I instructed the other interviewers to list any irregularities that occurred during the course of each interview. An analysis of variance of the means for liking to be touched showed a statistically significant difference ( $\mathrm{p}<.02$ ) between the mean ratings obtained by the two student interviewers. These two interviewers each processed 6 nursing home participants. Examination of the rating forms showed no ratings for "Like very much" in one group and no ratings for "Dislike very much" in the other group. Both of these patterns appeared in the 20 sets of ratings obtained by the third interviewer. The overall significance for the difference in the means for the three interviewers was $p<.08$. I have no explanation for the difference in the mean ratings obtained by the two interviewers.

\section{RELIABILITY}

Coefficient alpha, which is a measure of internal consistency of the ratings of the scenes, was used as a measure of the reliability of the total score. The value obtained for alpha was .87 .

\section{CONCURRENT VALIDITY}

An attempt was made to establish concurrent validity by having 5 female staff members of the nursing home give a general rating as to how each of the 12 participants seem to like being touched. Each staff member rated only those participants with whom she was familiar. The same concurrent 
validity check was not attempted in the retirement homes because of the highly independent living arrangements of most of the residents.

The test for concurrent validity resulted in a correlation of .30 between self-reported mean liking to be touched and mean ratings of behaviors as observed by staff for those participants 1 iving in the nursing home. For only 12 cases this correlation was not statistically significant, but it matched Mischel's (1979) . 30 "personality coefficient" for ratings between self-report and observers. Mischel (1977) introduced the term "personality coefficient" to label the usual . 30 correlation found between noncognitive personality measures based on dissimilar methods, such as, ratings and relevant behavior (p. 742). 
CHAPTER I I

\section{RESULTS}

The following statistical results were obtained by means of SPSS/PC (Norusis, 1984) software.

\section{DEMOGRAPHIC DATA}

The difference in the mean age for the two groups was not statistically significant $(\underline{t}(30)=-1.23$, $\underline{p}<.23)$, with the mean age of those in the nursing home being 83.33 with a SD of 4.44, and the mean age for those in the retirement homes being 81.0 years with a SD of 6.25 . Comparison of range of ages showed 5 participants between 65 and 75 years old in the retirement homes with the range being from 65 to 90 years. The nursing home participant's ages were more clustered with no participants between 65 and 75 years and the range being 77 to 91 years.

A11 other demographic data that were recorded for both groups also showed no statistically significant differences. Therefore, for reporting demographic statistics, the nursing home residents were pooled with the retirement home residents. The mean years of education for the 32 participants was 11.31 with a SD of 2.98 and a range of 8 to 18 years. Twenty-four of the participants worked outside the home with the mean number of years worked outside being 
17.44 with a SD of 15.86 and a range of 4 to 50 years. Of the 32 participants, 31 were or had been married with 28 having had one marriage and 3 having had two marriages. Present marital status was 1 participant who was single, 2 who were divorced ( 3 years and 47 years), 4 who were married, and 24 who were widowed with the mean years widowed being 12.81 with a SD of 12.81 .

Among the participants 23 had one or more sisters and 21 had one or more brothers. None of the participants had either a stepsister or a stepbrother; however, 5 had one or more half sisters, 4 had one half brother, and 1 had two half brothers. Of the 28 sisters and half sisters, 14 were still living, and of the 26 brothers and half brothers, 9 were still living.

Of the participants, 20 had one or more daughters and 1 participant had a stepdaughter. Of the 27 daughters, 26 were still living. There was one or more sons among 20 of the participants and 2 participants had one stepson. Of the 29 sons and stepsons 24 were still living.

RANK ORDER OF LIKING OF TYPES OF TOUCH

The most liked type of touch was that of a female staff member giving a foot massage, and the least liked type of touch was that of a male staff member helping with toileting (see Table I). 
TABLE I

RANK ORDER OF LIKING OF TYPES OF TOUCH

\begin{tabular}{clcr}
\hline \hline Rank & \multicolumn{1}{c}{ Type of touch } & Mean & SD \\
\hline 1 & Female giving foot massage & 1.63 & .66 \\
2 & Female brushing hair & 1.81 & 1.00 \\
3 & Female giving back rub & 1.91 & .93 \\
4 & Male helping to stand & 1.94 & .62 \\
5 & Male giving foot massage & 1.97 & .90 \\
6 & Female helping to dress & 2.00 & .95 \\
7 & Female helping to stand & 2.03 & .69 \\
8 & Female arm around shoulder & 2.09 & .69 \\
9 & Male giving back rub & 2.22 & 1.01 \\
10 & Male brushing hair & 2.28 & 1.11 \\
11 & Female helping with shower & 2.38 & .83 \\
12 & Female holding hand & 2.47 & .95 \\
13 & Male holding hand & 2.53 & 1.08 \\
14 & Female helping with toileting & 2.66 & 1.10 \\
15 & Male arm around shoulder & 2.75 & .92 \\
16 & Female stroking cheek & 2.84 & .92 \\
17 & Male stroking cheek & 3.34 & .90 \\
18 & Male helping to dress & 3.69 & .78 \\
19 & Male helping with shower & 3.88 & 1.13 \\
20 & Male helping with toileting & 4.09 & .69 \\
\hline
\end{tabular}

COMPARISON OF LIKING OF TYPES OF TOUCH RELATED TO SEX OF STAFF MEMBER

For 9 out of the 10 types of touch, participants preferred to be touched by a female staff over a male staff member. The exception was in being helped to stand; however, 
the difference was not statistically significant. For 6 of the 10 types of touch the difference was statistically significant and favored the female staff member (see Table II).

\section{TABLE II}

LIKING OF TYPES OF TOUCH RELATED TO SEX OF STAFF MEMBER

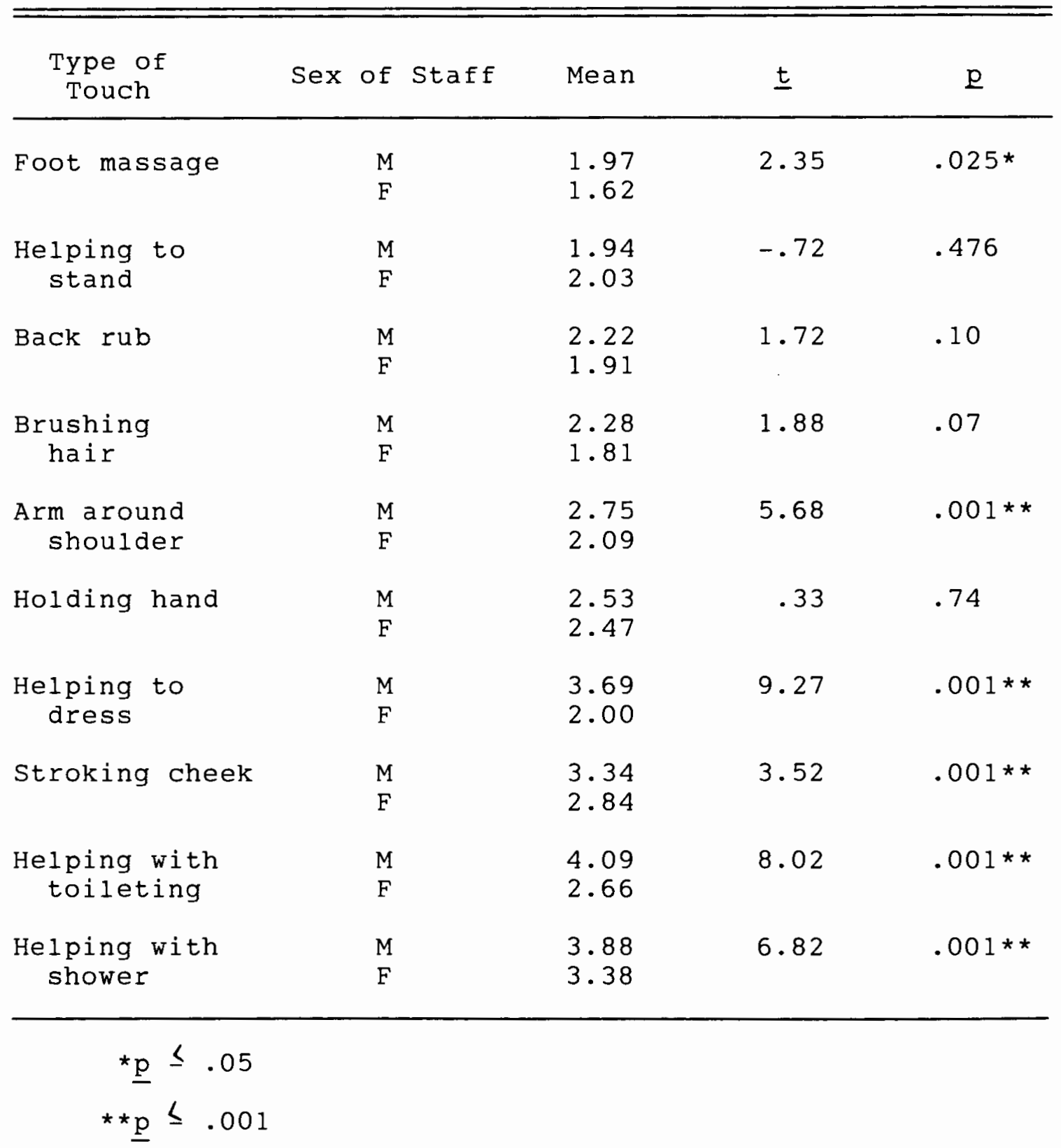


COMPARISON OF LIKING OF TYPES OF TOUCH

RELATED TO PLACE OF RESIDENCE

There were 4 statistically significant differences in the liking of the 20 types of touch between nursing home and retirement home participants (see Table III). With 20 different $\underline{t}$ tests at the .05 level of significance, the probability of 4 of the 20 occurring by chance is .003 . In the case of foot massage, for both male and female staff, retirement home participants reported a greater liking than nursing home participants. Other significant differences occurred with helping with toileting. For male staff, nursing home participants reported less disliking than those in the retirement homes. However, for female staff, nursing home participants reported liking, and retirement home participants reported neither liking nor disliking help with toileting.

In 2 cases there was a significant difference in the variances in the distributions for the nursing home and retirement home participants. For both Foot massage/Female and Back rub/Female the retirement home participants had a greater range of responses indicating less agreement with respect to liking. 
TABLE III

LIKING OF TYPES OF TOUCH RELATED TO PLACE OF RESIDENCE

\begin{tabular}{|c|c|c|c|c|c|}
\hline $\begin{array}{l}\text { Type of } \\
\text { Touch }\end{array}$ & $\begin{array}{l}\text { Place of } \\
\text { Resi- } \\
\text { dence }\end{array}$ & Mean & SD & $\underline{t}$ & p \\
\hline $\begin{array}{l}\text { Foot massage/ } \\
\text { Male }\end{array}$ & $\mathrm{N}_{\mathrm{b}}^{\mathrm{a}}$ & $\begin{array}{l}2.42 \\
1.70\end{array}$ & $\begin{array}{l}.79 \\
.86\end{array}$ & 2.34 & $.03 *$ \\
\hline $\begin{array}{l}\text { Foot massage/ } \\
\text { Female }\end{array}$ & $\begin{array}{l}\mathrm{N} \\
\mathrm{R}\end{array}$ & $\begin{array}{l}1.92 \\
1.45\end{array}$ & $\begin{array}{l}.29 \\
.76\end{array}$ & 2.47 & $.02 *$ \\
\hline $\begin{array}{l}\text { Helping to } \\
\text { stand/Male }\end{array}$ & $\begin{array}{l}\mathrm{N} \\
\mathrm{R}\end{array}$ & $\begin{array}{l}2.08 \\
1.85\end{array}$ & $\begin{array}{l}.67 \\
.59\end{array}$ & 1.03 & .31 \\
\hline $\begin{array}{l}\text { Helping to } \\
\text { stand/Female }\end{array}$ & $\begin{array}{l}\mathrm{N} \\
\mathrm{R}\end{array}$ & $\begin{array}{l}1.92 \\
2.10\end{array}$ & $\begin{array}{l}.67 \\
.72\end{array}$ & -.72 & .48 \\
\hline Back rub/Male & $\begin{array}{l}\mathrm{N} \\
\mathrm{R}\end{array}$ & $\begin{array}{l}2.50 \\
2.05\end{array}$ & $\begin{array}{r}.80 \\
1.10\end{array}$ & 1.23 & .23 \\
\hline Back rub/Female & $\begin{array}{l}N \\
R\end{array}$ & $\begin{array}{l}2.00 \\
1.85\end{array}$ & $\begin{array}{r}.43 \\
1.14\end{array}$ & .53 & .60 \\
\hline $\begin{array}{l}\text { Brushing hair/ } \\
\text { Male }\end{array}$ & $\begin{array}{l}\mathrm{N} \\
\mathrm{R}\end{array}$ & $\begin{array}{l}2.67 \\
2.05\end{array}$ & $\begin{array}{l}.89 \\
1.19\end{array}$ & 1.55 & .13 \\
\hline $\begin{array}{l}\text { Brushing hair/ } \\
\text { Female }\end{array}$ & $\begin{array}{l}N \\
R\end{array}$ & $\begin{array}{l}2.00 \\
1.70\end{array}$ & $\begin{array}{l}.74 \\
1.13\end{array}$ & .82 & .42 \\
\hline $\begin{array}{l}\text { Arm around } \\
\text { shoulder/Male }\end{array}$ & $\begin{array}{l}\mathrm{N} \\
\mathrm{R}\end{array}$ & $\begin{array}{l}2.75 \\
2.75\end{array}$ & $\begin{array}{l}.96 \\
.91\end{array}$ & .00 & 1.00 \\
\hline $\begin{array}{l}\text { Arm around } \\
\text { shoulder/Female }\end{array}$ & $\begin{array}{l}\mathrm{N} \\
\mathrm{R}\end{array}$ & $\begin{array}{l}2.17 \\
2.05\end{array}$ & $\begin{array}{l}.72 \\
.69\end{array}$ & .46 & .65 \\
\hline $\begin{array}{l}\text { Holding hand/ } \\
\text { Male }\end{array}$ & $\begin{array}{l}\mathrm{N} \\
\mathrm{R}\end{array}$ & $\begin{array}{l}2.67 \\
2.45\end{array}$ & $\begin{array}{l}1.07 \\
1.10\end{array}$ & .54 & .59 \\
\hline $\begin{array}{l}\text { Holding hand/ } \\
\text { Female }\end{array}$ & $\begin{array}{l}\mathrm{N} \\
\mathrm{R}\end{array}$ & $\begin{array}{l}2.67 \\
2.35\end{array}$ & $\begin{array}{l}.89 \\
.99\end{array}$ & .91 & .37 \\
\hline $\begin{array}{l}\text { Helping to } \\
\text { dress/Male }\end{array}$ & $\begin{array}{l}\mathrm{N} \\
\mathrm{R}\end{array}$ & $\begin{array}{l}3.42 \\
3.85\end{array}$ & $\begin{array}{l}.67 \\
.81\end{array}$ & -1.56 & .13 \\
\hline $\begin{array}{l}\text { Helping to } \\
\text { dress/Female }\end{array}$ & $\begin{array}{l}\mathrm{N} \\
\mathrm{R}\end{array}$ & $\begin{array}{l}2.08 \\
1.95\end{array}$ & $\begin{array}{r}1.00 \\
.94\end{array}$ & .38 & .71 \\
\hline
\end{tabular}


TABLE III-- Continued

\begin{tabular}{|c|c|c|c|c|c|}
\hline $\begin{array}{l}\text { Type of } \\
\text { Touch }\end{array}$ & $\begin{array}{l}\text { Place of } \\
\text { Resi- } \\
\text { dence }\end{array}$ & Mean & $\mathrm{SD}$ & $\underline{t}$ & $\underline{\mathrm{p}}$ \\
\hline $\begin{array}{l}\text { Stroking cheek/ } \\
\text { Male }\end{array}$ & $\begin{array}{l}\mathrm{N} \\
\mathrm{R}\end{array}$ & $\begin{array}{l}3.33 \\
3.35\end{array}$ & $\begin{array}{l}.89 \\
.93\end{array}$ & -.05 & .96 \\
\hline $\begin{array}{l}\text { Stroking cheek/ } \\
\text { Female }\end{array}$ & $\begin{array}{l}\mathrm{N} \\
\mathrm{R}\end{array}$ & $\begin{array}{l}2.92 \\
2.80\end{array}$ & $\begin{array}{l}.90 \\
.95\end{array}$ & .34 & .73 \\
\hline $\begin{array}{l}\text { Helping with } \\
\text { toileting/Male }\end{array}$ & $\begin{array}{l}\mathrm{N} \\
\mathrm{R}\end{array}$ & $\begin{array}{l}3.75 \\
4.30\end{array}$ & $\begin{array}{l}.62 \\
.66\end{array}$ & $-2 \cdot 34$ & $.03 *$ \\
\hline $\begin{array}{l}\text { Helping with } \\
\text { toileting/Female }\end{array}$ & $\begin{array}{l}\mathrm{N} \\
\mathrm{R}\end{array}$ & $\begin{array}{l}2.17 \\
2.95\end{array}$ & $\begin{array}{r}.72 \\
1.19\end{array}$ & -2.06 & $.05 *$ \\
\hline $\begin{array}{l}\text { Helping with } \\
\text { shower/Male }\end{array}$ & $\begin{array}{l}\mathrm{N} \\
\mathrm{R}\end{array}$ & $\begin{array}{l}3.92 \\
3.85\end{array}$ & $\begin{array}{r}.79 \\
1.31\end{array}$ & .16 & .88 \\
\hline $\begin{array}{l}\text { Helping with } \\
\text { shower/Female }\end{array}$ & $\begin{array}{l}\mathrm{N} \\
\mathrm{R}\end{array}$ & $\begin{array}{l}2.08 \\
2.55\end{array}$ & $\begin{array}{l}.79 \\
.83\end{array}$ & -1.57 & .13 \\
\hline
\end{tabular}

$\mathrm{a}_{\mathrm{N}}=$ Nursing home participants

$\mathrm{b}_{\mathrm{R}}=$ Retirement home participants

${ }_{\mathrm{p}} \leq .05$.

PREDICTION OF MEAN LIKING BY

DEMOGRAPHIC CHARACTERISTICS

A multiple regression analysis identified only 1 demographic characteristic of the 24 recorded which predicted general liking to being touched. That characteristic was the number of living brothers $(\underline{R}=.40)$. 
CHAPTER IV

\section{DISCUSSION}

The purpose of this study was to establish what elderly females in nursing and retirement homes report to be liked and disliked forms of touching by male and female staff.

The set of 20 scenes to be rated produced an acceptable range of responses from a mean of 1.62 for the most liked type of touching to a mean of 4.09 for the most disliked type of touching. The distribution was skewed to the disliked end with the majority of means clustered between 1.5 and 2.5 indicating that more than half the types of touching were reported to be liked by the participants.

Although the difference was not great, the participants in the two retirement homes liked certain of the caregiving touching less than those in the nursing home. Through the informal conversations that I had with those in the retirement homes, I learned that most had not experienced the more intimate caregiving procedures that those in the nursing home had experienced. One possibility for the greater liking by the nursing home residents is that as a procedure involving intimate touching becomes essential, 
the person needing the procedure tends to like the procedure more.

other possible effects on responses of participants of both the nursing and the retirement homes could be the number of visitors the person has, the number of outings from the home, and other types and amounts of stimulation that the person experiences.

\section{FACTOR ANALYSIS OF RATINGS}

A principal-components factor analysis was performed, but because of the small number of cases and lack of cross validation procedures, the results should be considered inconclusive. Because the analysis came out so well, the results are included so to encourage continued research using a larger sample and cross validation techniques. The results indicated that the 20 -item rating procedure contained 7 dimensions. Varimax rotation was applied to the factor loading matrix. Based on the rotated factor matrix, these factors in order of extraction appear to me to be:

1. Liked touching by a male

2. Acceptable nonessential touching

3. Disliked touching by a male

4. Intimate touching by a female

5. Acceptable touching by a female

6. Liked nonessential touching

7. Neutral nonessential touching

(See Appendix I for the rotated factor matrix.)

The factor analysis of the ratings showed that the set of rating scales did not represent a single dimension of liking to disliking. Rather, the set was factorially complex with 7 different dimensions. Those dimensions appear 
to involve the sex of the staff member, the type of touch, and the degree of liking or disliking the type of touch depicted. The following is my rationale for labeling each of the factors (see Appendix C, Figures 1 through 20):

Factor 1--Liked Touching by a Male

The high loadings on Factor 1 included Figures 7 (Male staff--brushing hair), 1 (Male staff--giving foot massage), and 3 (Male staff--helping to stand). These figures show a male providing touching which was rated as liked.

Factor 2--Acceptable Nonessential Touching

The high loadings included Figures 9 (Male staff--arm around shoulder), and 10 (Female staff--arm around shoulder). Factor 3--Disliked Touching by a Male

The high loadings included Figures 18 (Male staff-assisting with toileting), 13 (Male staff--helping to dress), and 20 (Male staff--helping with shower). All of these were rated as being disliked.

Factor 4--Intimate Touching by a Female

The high loadings included Figures 17 (Female staff-assisting with toileting), and 19 (Female staff--helping with shower). Although neither was liked, participants preferred having a female help with intimate care over a male.

\section{Factor 5--Acceptable Touching by a Female}

The high loadings included Figures 12 (Female staff-holding hand), 4 (Female staff--helping to stand), and 14 (Female staff-helping to dress). 
Factor 6--Liked Nonessential Touching

The high loadings included Figures 8 (Female--brushing hair), 1 (Male--giving a foot massage), and 6 (Female-giving a back rub). Each of these types of touching was liked.

Factor 7--Neutral Nonessential Touching

The high loadings on this factor included Figures 15 (Male--stroking cheek), and 16 (Female--stroking cheek). Both of these were rated as being neutral.

The large number of factors suggests that touch is perceived in a complex manner. The large number of factors also suggests that there may be a cognitive as well as an affective component since it appears that the perception of touch can't be reduced to simple liking or disliking.

The factor which suggests liking for nonessential touching supports the importance of touching as a form of interaction which goes beyond that which is required for essential caregiving.

\section{ITEM ANALYSIS BY STEPWISE MULTIPLE REGRESSION}

Stepwise multiple regression determined the relative efficiency of the scenes in predicting a total score for liking to be touched which was based on those scenes. Although the item analysis showed that to predict the total score the number of scenes could be reduced to 5 , this finding would have to be cross validated. Also, overall total or mean score for liking was not the main focus of 
this study. The scene which initially showed the highest positive relationship to total score was scene 18 (Female staff--arm around shoulder) with $\underline{R}=.67$. Next, Scene 17 (Male staff--helping to dress) was entered into the regression equation with the resulting $\underline{R}=.81$. In all, 11 items were entered into the regression equation before the limit of statistical significance was reached. All relationships were positive. During analysis, Scene 18 was removed because of its high correlation with scenes subsequently added. For results of this stepwise multiple regression see Table IV.

- The results of the item analysis provided a different perspective of the complexity of the results than those derived from the factor analysis of the rating procedure. The purpose of the factor analysis was to determine the dimensions to be found in the results of the ratings by residents. Seven clusters of items related to the 7 factors were obtained. The purpose of the item analysis was to obtain a single cluster of items which were highly correlated with the total score for each participant but had low correlations with one another. The result of the item analysis was a cluster of 11 items which produced a multiple $\underline{R}$ of .99 . Although this value was inflated because the total score contains the score for each of the scenes, the number of scenes in the final equation and the correlation with total score were impressive. Like the results of the factor analysis, the multiple regression analysis also provided evidence of the statistical independence of the ratings from the scenes. 
In other words, the responses by residents were clearly not a function of a large general factor or an overriding response set such as social desirability.

TABLE IV

ITEM ANALYSIS BY STEPWISE MULTIPLE REGRESSION

\begin{tabular}{|c|c|c|c|c|}
\hline Scene ${ }^{a}$ & $\begin{array}{c}\text { Multiple } \\
\underline{R}\end{array}$ & square & Ratio & p \\
\hline 18 & .67 & .45 & 24.55 & $.001 *$ \\
\hline 18,17 & .81 & .66 & 27.61 & $.001 *$ \\
\hline $18,17,8$ & .88 & .78 & 32.41 & $.001 *$ \\
\hline $18,17,8,7$ & .92 & .86 & 39.89 & $.001 *$ \\
\hline $18,17,8,7,4$ & .94 & .89 & 43.34 & $.001 *$ \\
\hline $18,17,8,7,4,6$ & .97 & .93 & 56.99 & $.001 *$ \\
\hline $17,8,7,4,6$ & .96 & .92 & 63.24 & $.001 *$ \\
\hline $17,8,7,4,6,2$ & .97 & .94 & 66.79 & $.001 *$ \\
\hline $\begin{array}{l}17,8,7,4,6,2, \\
14\end{array}$ & .98 & .96 & 74.93 & $.001 *$ \\
\hline $\begin{array}{l}17,8,7,4,6,2, \\
14,9\end{array}$ & .98 & .97 & 86.37 & $.001 *$ \\
\hline $\begin{array}{l}17,8,7,4,6,2, \\
14,9,12\end{array}$ & .99 & .98 & 106.60 & $.001 *$ \\
\hline $\begin{array}{l}17,8,7,4,6,2, \\
14,9,12,10\end{array}$ & .99 & .99 & 163.79 & $.001 *$ \\
\hline $\begin{array}{l}17,8,7,4,6,2, \\
14,9,12,10,11\end{array}$ & 1.00 & .99 & 190.57 & $.001 *$ \\
\hline
\end{tabular}
tions.

${ }^{a}$ See Appendix G, p. 50, for a list of Scene descrip-

$$
{ }^{*} \underline{\underline{p}} \leq .001
$$


CONSTRUCT VALIDITY

The purpose of this study was to obtain information concerning the construct liking to be touched. Whether the procedure developed in this study to establish the degree to which a person liked being touched actually measures that construct would require further research. I know of no independent measure of that construct which I could use to correlate with each participant's overall liking to be touched other than the mean staff rating which seemed appropriate for only the nursing home participants.

The procedure used in this study may have been picking up on one or more other constructs. Possible competing constructs would be those classified under personality traits or dispositions. One way to check would be to administer scales designed to measure hypothetical global traits such as those currently listed by Goldberg (1987) which include: conscientiousness, surgency, culture, agreeableness, emotional stability, religiosity, and ability. Scores on selected trait measures would then be correlated with the mean liking to be touched score for each participant to determine possible relationships.

\section{LIKING AND DISLIKING OF TOUCHING}

With respect to liking and disliking of touching, there are several types of touching which could be classified as nonessential, but which are liked by a majority of the participants in this study. These include foot massage, 
preferred over male staff in all but one type of touch. these types of touching were also the preferred types of touching given by a male. If essential or intimate care is required, a female staff member is preferred with the exception of being helped to stand. The greater physical strength of males is a likely explanation for this difference.

The most disliked types of touching were helping with a shower and helping with toileting--both of which can be categorized as essential and intimate touching. The third least liked type of touch was stroking the cheek; however this fell in the neutral range rather than in the disliked range.

These findings are consistent with dewever's (1977) finding that females responded with discomfort more often if the nurse was a male. The results of the present study did not support her finding that an arm around the shoulder was an uncomfortable, or disliked, type of touching. On the contrary, the mean rating (2.42) was in the range of liked (1.5 to 2.5$)$ types of touch.

The participants in this study seemed to like touching that could be categorized as affectionate or nonessential, while they generally disliked touching that could be categorized as nonaffectionate or essential. Touch may be categorized into inadvertent or intentional touch. The results of this study suggest that there are at least two 
example, the continuum may start with nonessential touch and extend to essential touch. There is also the possibility of a continuum ranging from impersonal to intimate.

\section{LOGISTICAL CONSIDERATIONS}

\section{$\underline{\text { Subjects }}$}

Although the problems were different, there was a problem getting volunteers in both the retirement homes and the nursing home. Permission from the administrator to contact residents directly was relatively easy in the retirement homes. Making contact was difficult since the residents live independently which makes them hard to track down.

In the nursing home, the extra requirement of securing permission from the person who was listed as the responsible party for the resident before contacting the resident added several days to the time frame, and some potential participants were lost because of denial of such permission, or because the responsible party could not be reached. Other problems in the nursing home included working around the routine of the home. Interviews could only be conducted during certain hours, and locating the resident was sometimes difficult. Also, although the actual interview only required about 10 minutes to complete, it usually took 45 minutes per interview because of the need to gain the 
confidence of the potential participant. Less time was required in the retirement homes with the average interview lasting 15 minutes.

One suggestion for those who plan a study using residents of retirement homes would be to attend several of the planned group events of the home and get to know some of the residents before asking them to participate. Familiarity with the researcher would establish a basis for trust, and should promote a cooperative response from more residents. Photos and Sketches. Standardization of the pairs of photos and sketches would reduce possible effects which may have been created by the differences that were present in the pairs used in this study. One way to accomplish standardization would be to use one person whose physical size could be either male or female, paying special attention to the hands. The model would wear a long-sleeved unisex uniform. Through photographic procedures, a male head and face and a female head and face could be superimposed over the model's head and face. There are other potential methods to achieve standardization.

Informed Consent. While many elderly people are willing to participate in short studies, some are fearful of signing a document that seems complicated, such as an informed consent form. This fear could eliminate otherwise willing participants. To avoid this problem, arrangements can be made to have a witness--a responsible person who is not connected with the study--sign for the resident. 


\section{IMPLICATIONS OF THIS STUDY}

Although many residents of retirement and nursing homes report liking several types of nonessential touch, several residents reported that they did not like to be touched in this way. Keeping this in mind, caution should prevail when a staff person, either male or female, approaches an individual resident with or without intent to touch that person.

Since the selection of participants for this study was not random, more research in this area is necessary before results can be generalized to other retirement and nursing home residents. Also, no male residents were included, and so there is no way of knowing from this study what males would like or dislike in the way of being touched. 
Adams, D. (1969). Analysis of a life satisfaction index. Journal of Gerontology, 24, 470-474.

Aguilera, D. C. (1967). Relationships between physical contact and verbal interaction between nurses and patients. Journal of Psychiatric Nursing, 5, 5-21.

Barnett, K. (1972). A survey of the current utilization of touch by health team personnel with hospitalized patients. International Journal of Nursing Studies, ‥ 195-208.

Burnside, I. M. (1973). Touching is talking. American Journal of Nursing, 73, 2060-2063.

Chapin, H. D. (1915). A plea for accurate statistics in children's institutions. Transactions of the American Pediatric Society, 27, 180 .

dewever, M. K. (1977). Nursing home patients' perception of nurses' affective touching. Journal of Psychology, 96, 163-171.

Goldberg, L. R. (1987, March). The magical number five, plus or minus two: Some determinants of the dimensionality, and the content, or structural representations of personality traits. Paper presented at the mid-winter meeting of the society for Personality Assessment, San Francisco.

Hall, E. T. (1973). The silent language. New York: Anchor Books.

Hollinger, L. M. (1980). Perception of touch in the elderly. Journal of Gerontological Nursing, $\underline{6}$ (12), $741-746$.

Krieger, D. (1975). Therapeutic touch: The imprimatur of nursing. American Journal of Nursing, 75, 784-787.

Lowen, A. (1969). The betrayal of the body. New York: Collier Books.

McCorkle, R. (1974). Effectiveness of touch on seriously ill patients. Nursing Research, 23, 125-132. 
Miller, B. (1975). Iatrogenic and nursigenic effects of prolonged immobilization of the ill aged. Journal of the American Geriatrics Society, 23, 360-369.

Mischel, W. (1977). On the future of personality measurement. American Psychologist, 32(4), 246-254.

(1979). On the interface of cognition and personality: Beyond the person-situation debate. American Psychologist, 34(8), 740-754.

Montague, A. (1978). Touching. New York: Harper \& Row.

Morris, D. (1971). Intimate behavior. New York: Random House.

Norusis, M. J. (1984). SPSS/PC: SPSS for the IBM PC/XT. Chicago: SPSS Inc.

Preston, T. (1973). When words fail. American Journal of Nursing, 73, 2064-2066.

Rheingold, H. L. (1956). The modification of social responsiveness in institutionalized babies [Monograph]. Social Responsiveness in Child Development, 21 ( 2 , Series No. 63).

Rosentha1, M. J. (1952). Psychosomatic study of infantile eczema. Pediatrics, 10, 581-593.

Watson, W. H. (1975, Summer). The meanings of touch: Geriatric nursing. Journal of Communication, 104-112. 
APPENDIX A

INFORMED CONSENT

I, - hereby agree to serve as a subject in a research project on interactions being done by Mary Pintarich as a basis for her master's thesis in speech Communication at Portland State University, under the supervision of Dr. Robert Vogelsang.

I understand that the study involves being interviewed, and rating a set of twenty sketches which show two people interacting with each other.

It has been explained to me that the purpose of this study is to learn more about the interactions that take place between staff and residents in a nursing or retirement home.

I may not receive any direct benefit from participation in this study, but my participation may help to increase knowledge which may benefit others in the future.

Mary Pintarich has offered to answer any questions I may have about the study. I have been assured that all information I give will be kept confidential, and that I will not be identifiable in the findings.

I understand that participation in this study is voluntary and that I am free to withdraw at any time.

I have read and understand the foregoing information. DATE SIGNATURE 
APPENDIX B

DEMOGRAPHIC QUESTIONNAIRE

Date Subject number

Subject name: ( Years :

Occupation (s): How long:

Marital status: $S$ M $W$ D M W D

Past

No. marriages:

Siblings: Natural Step

Half

Female:

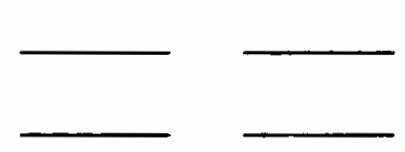

Male:

Children: Natural

Step

Female:

Living:

Male: 
APPENDIX C

PHOTOS AND SKETCHES, 1-20

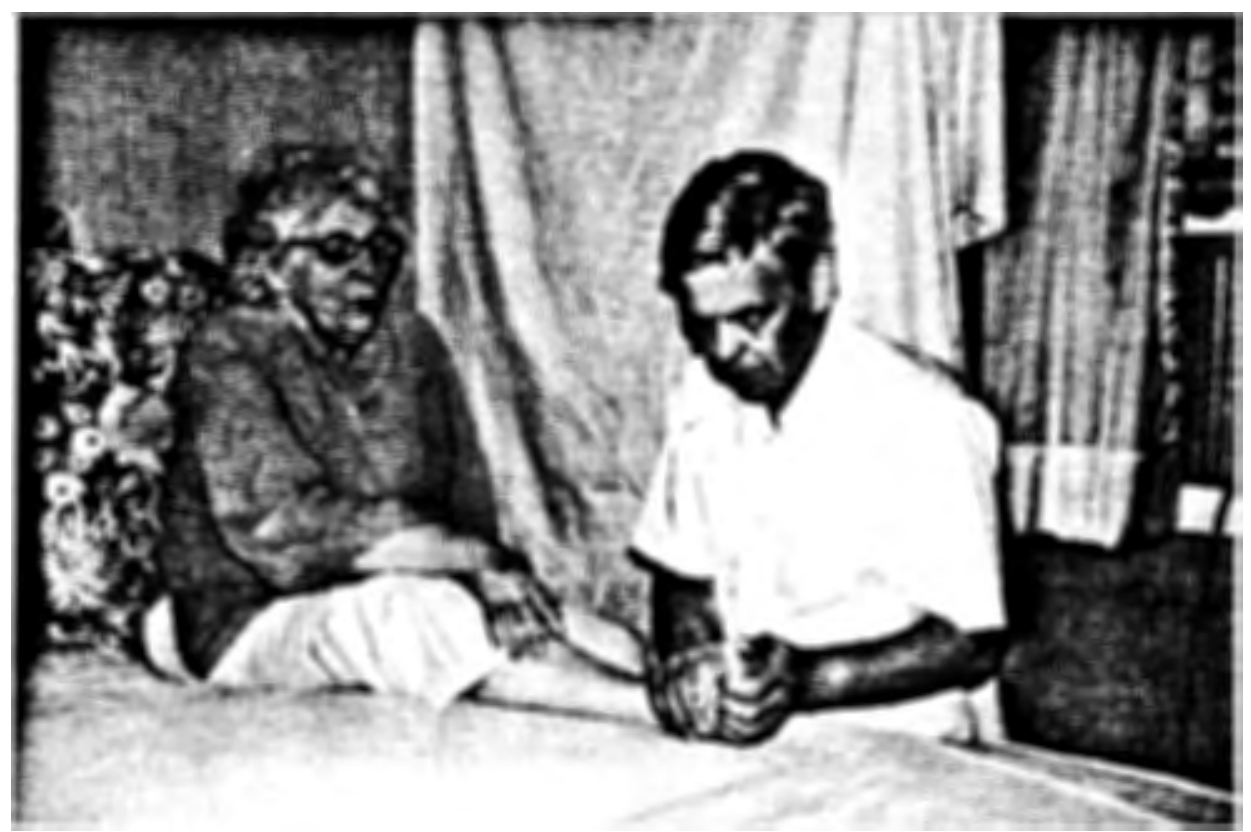

Figure 1. Male staff--giving foot massage.

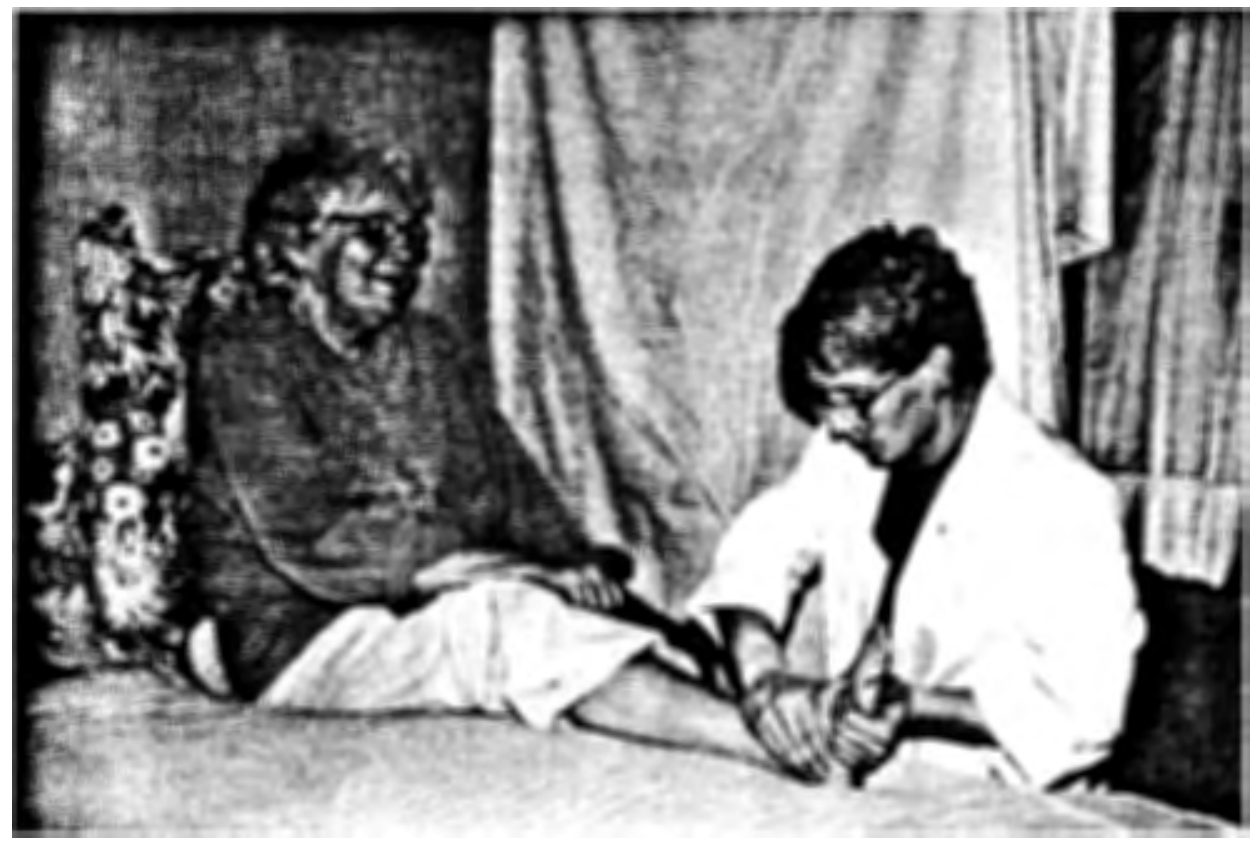

Figure 2. Female staff--giving foot massage. 


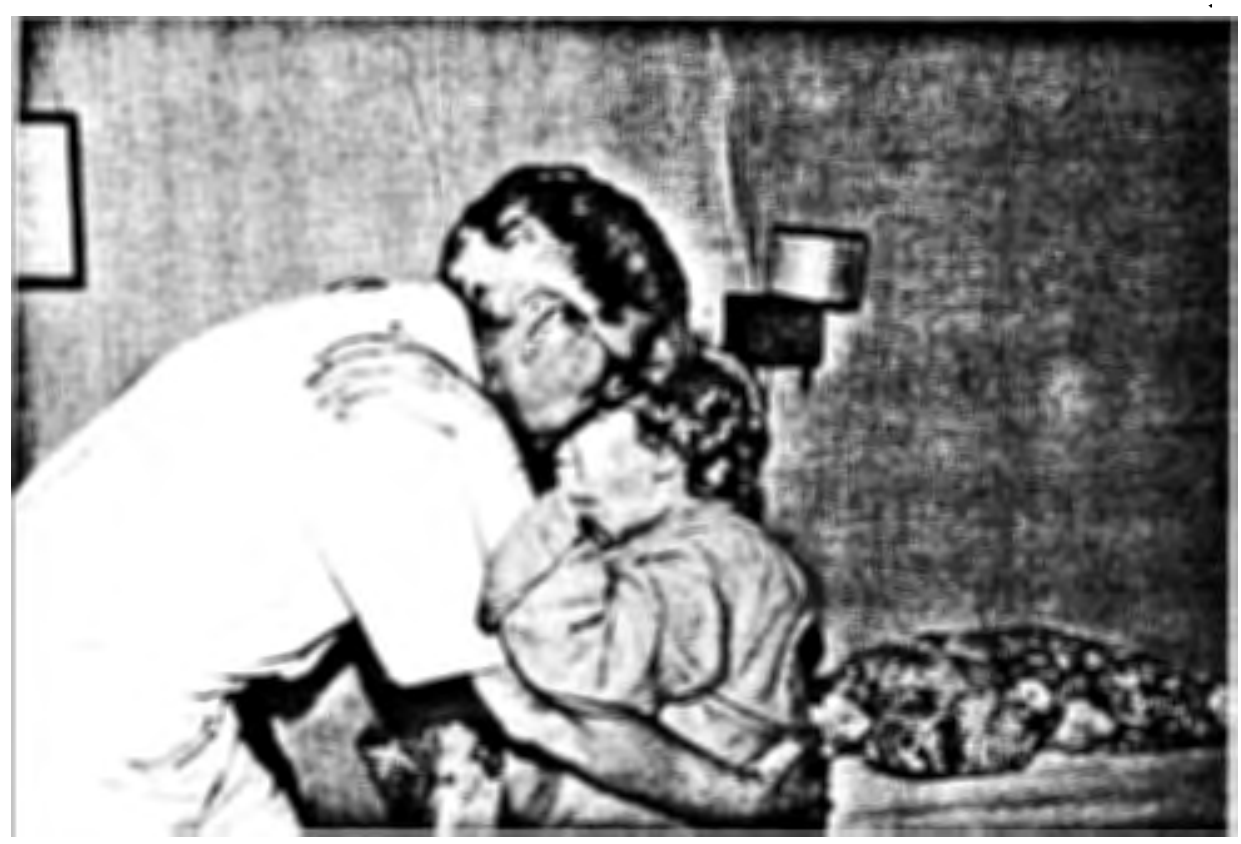

Figure 3. Male-staff--helping to stand.

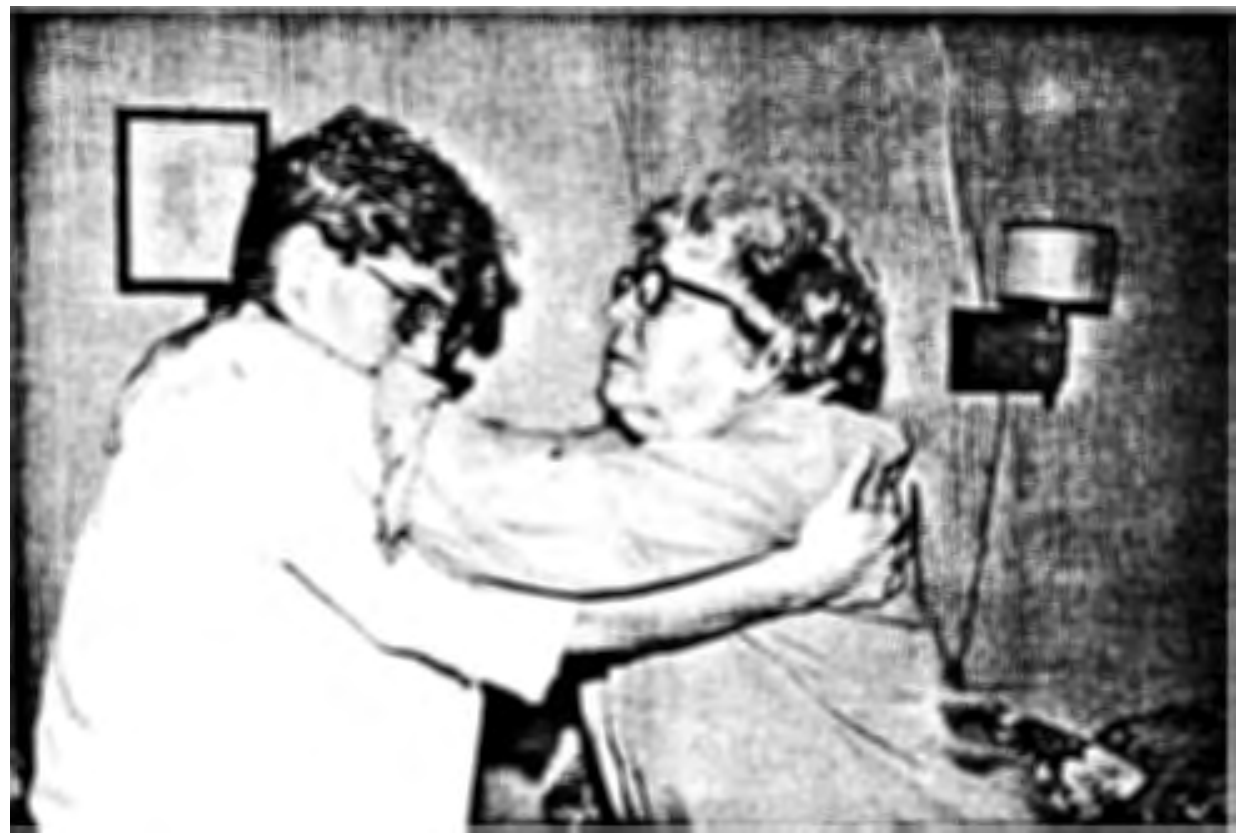

Figure 4. Female staff--helping to stand. 


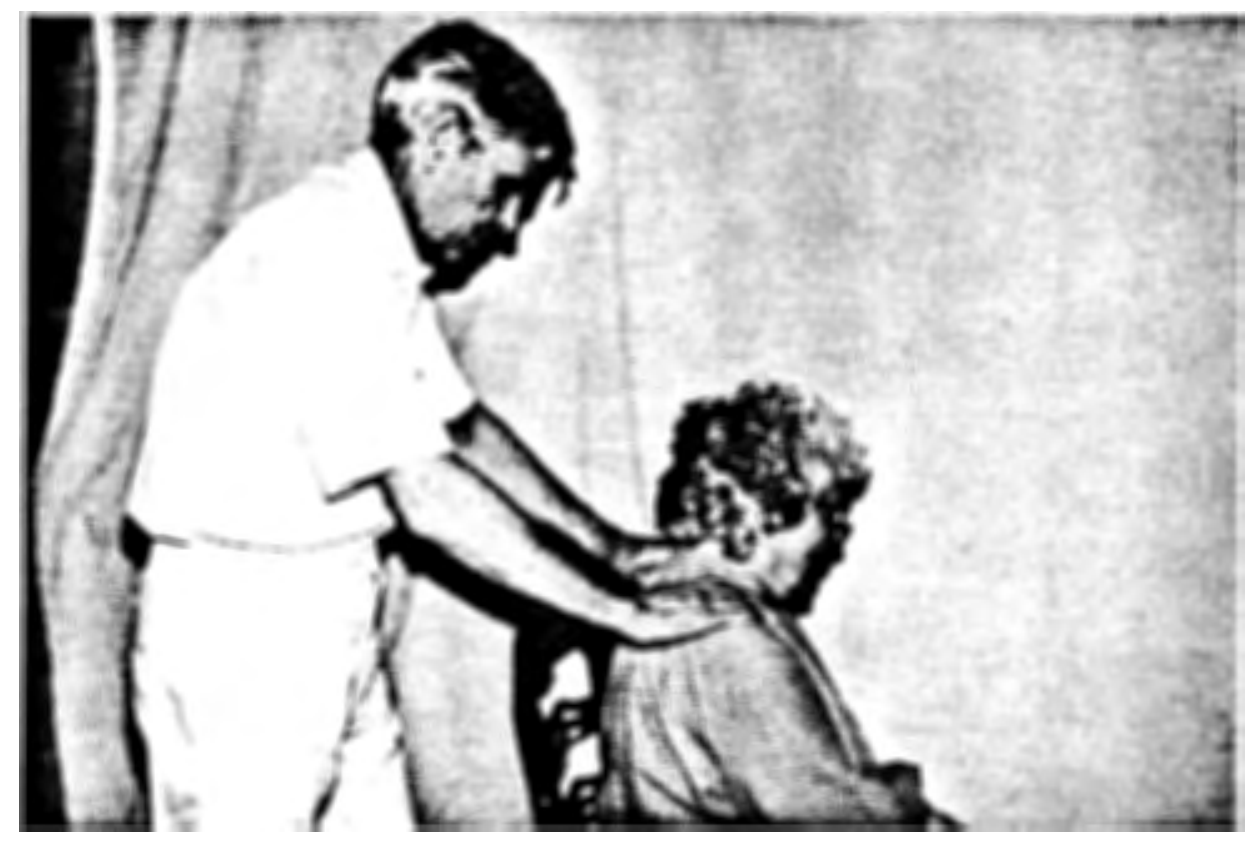

Figure 5. Male staff--giving back rub.

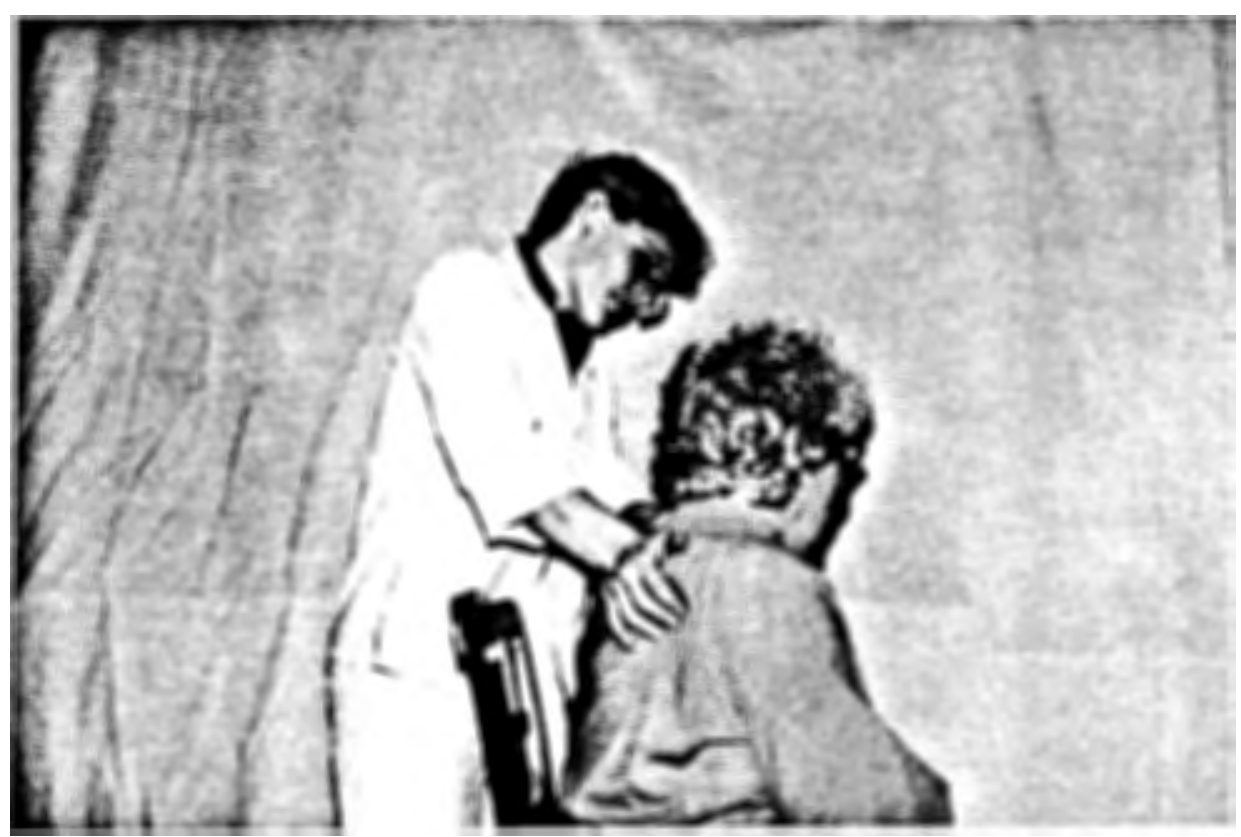

Figure 6. Female staff--giving back rub. 


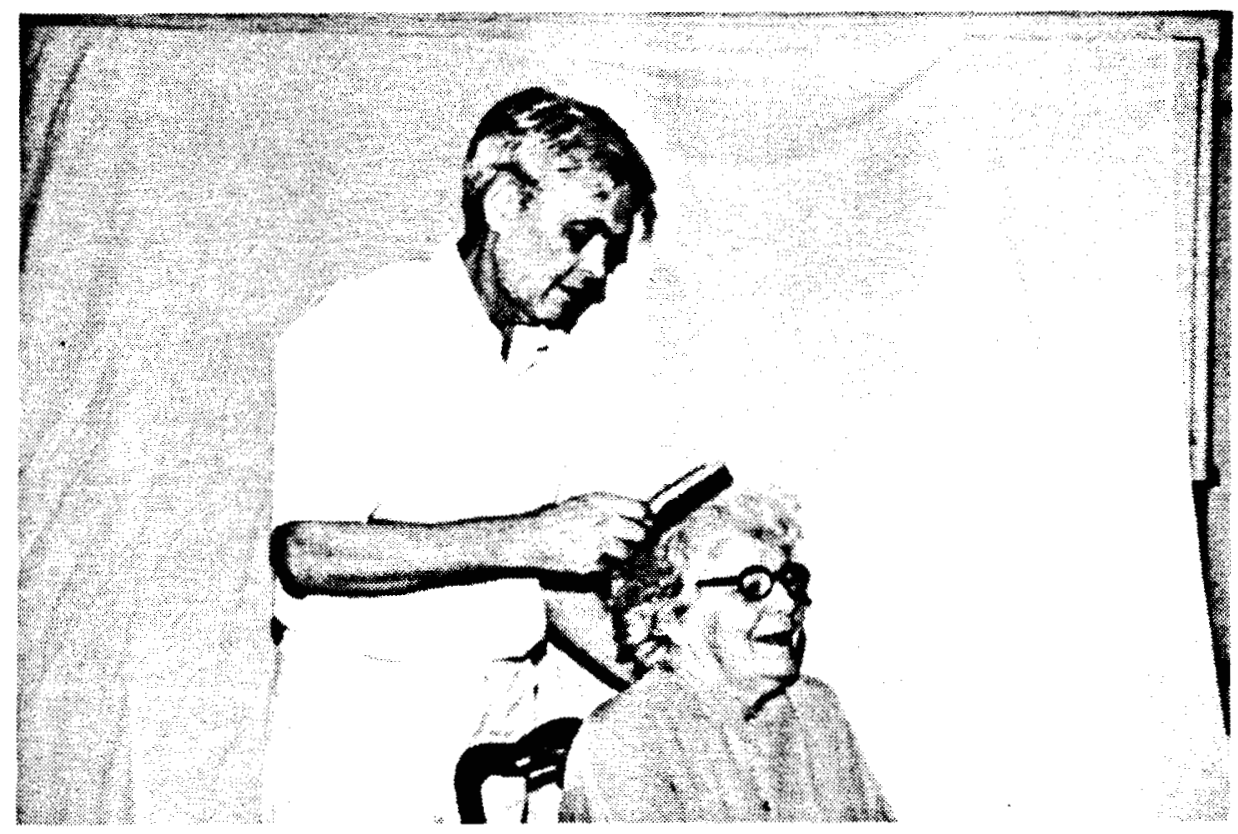

Figure 7. Male staff--brushing hair.
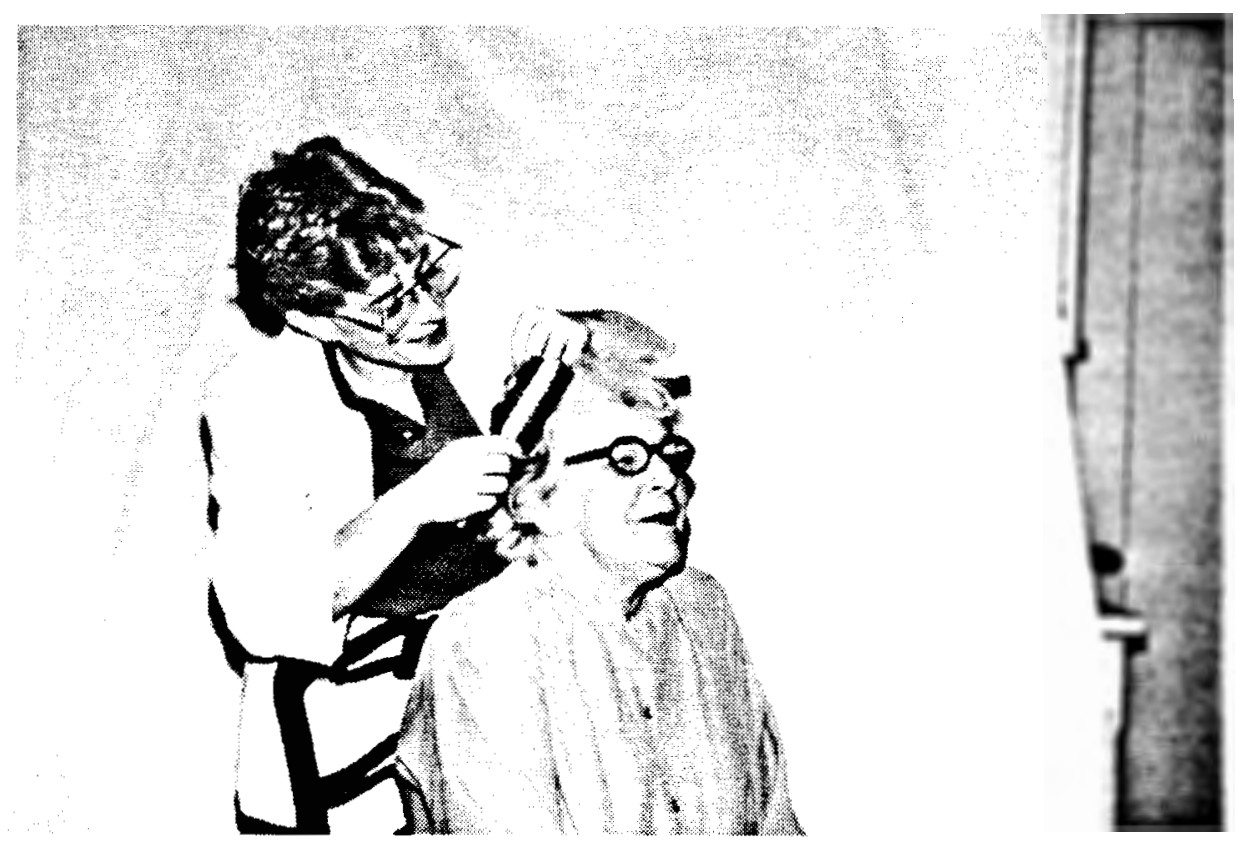

Figure 8. Female staff--brushing hair. 


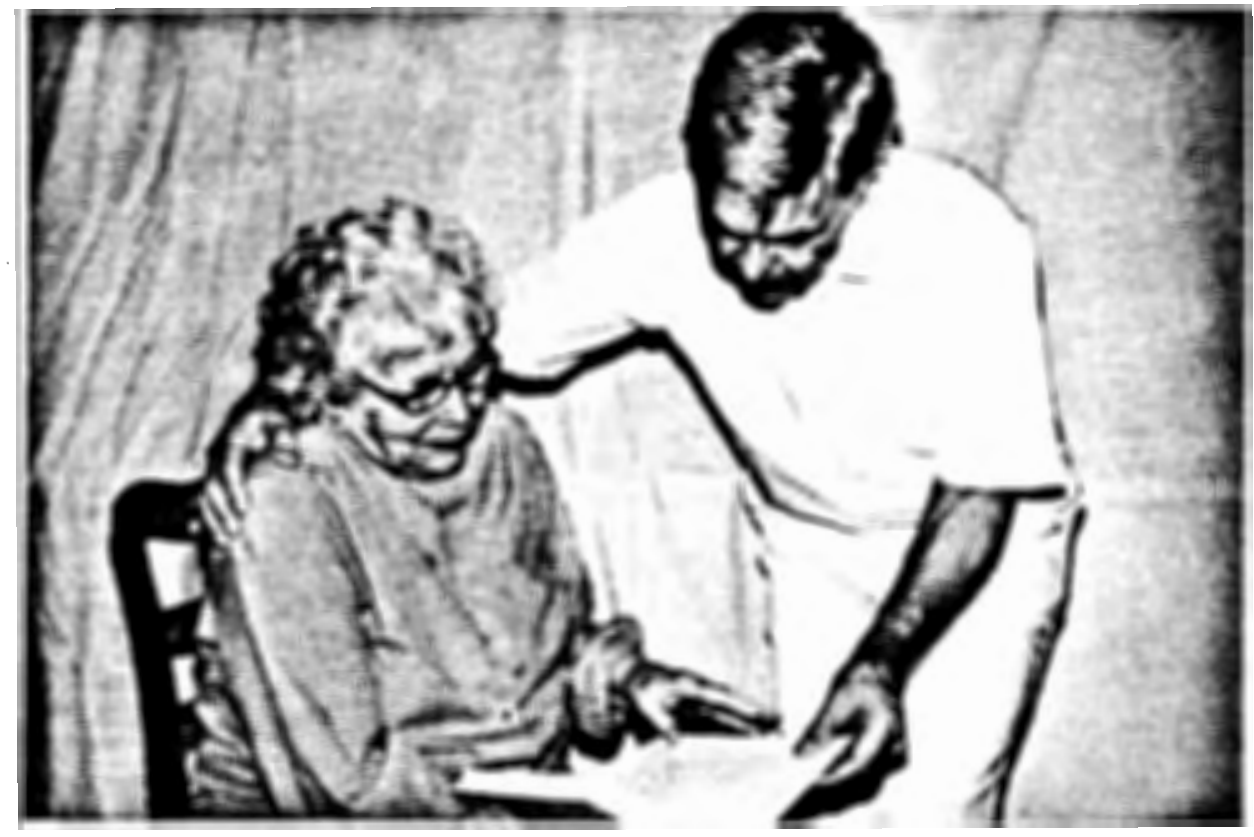

Figure 9. Male staff--arm around shoulder.

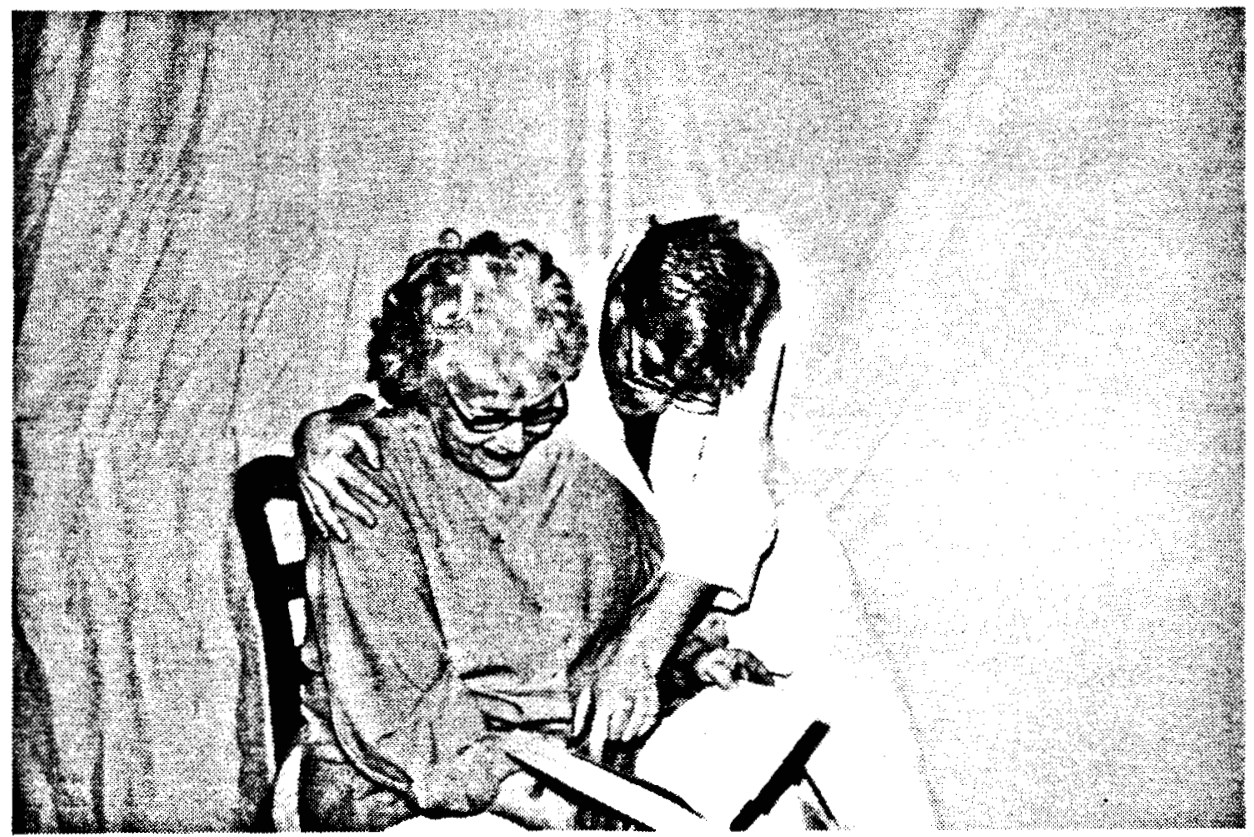

Figure 10. Female staff--arm around shoulder. 


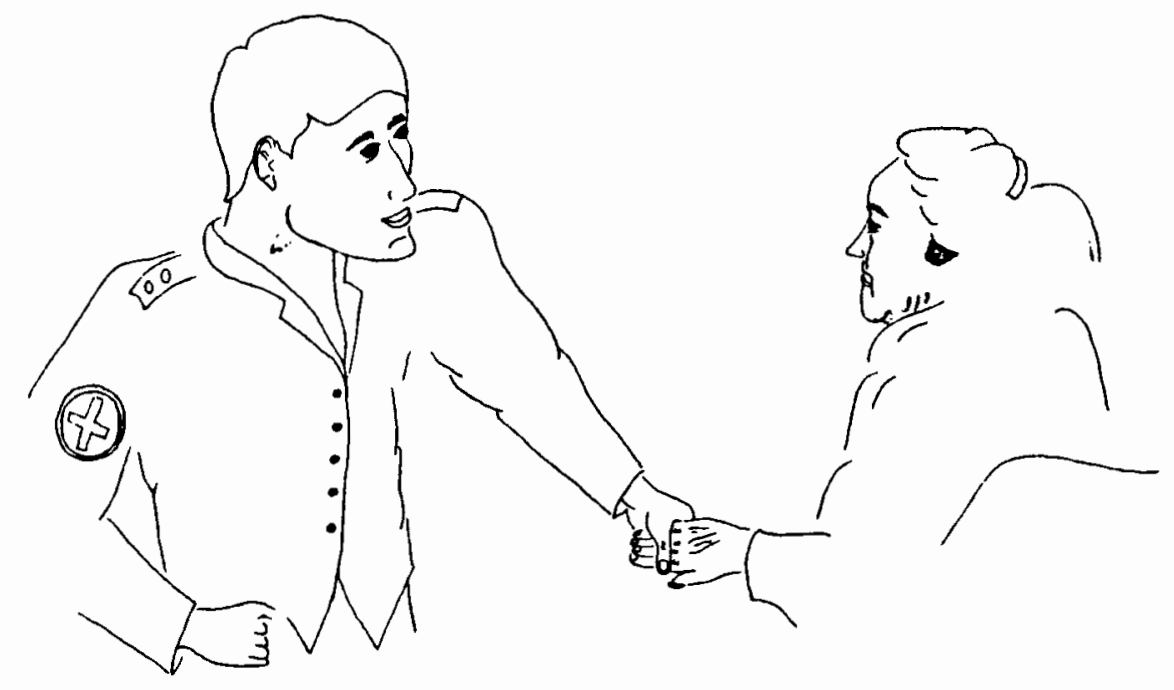

Figure 11. Male staff--holding hand.

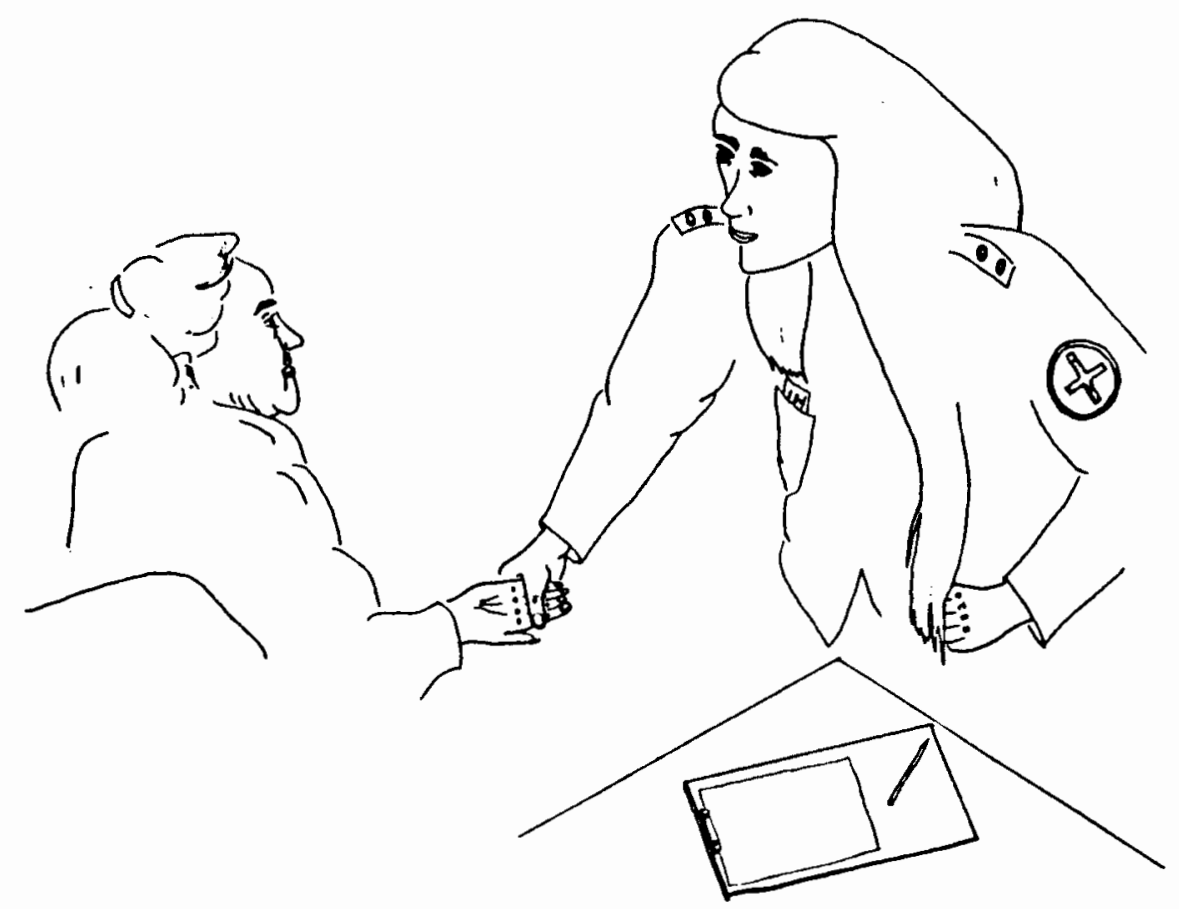

Figure 12. Female staff--holding hand. 


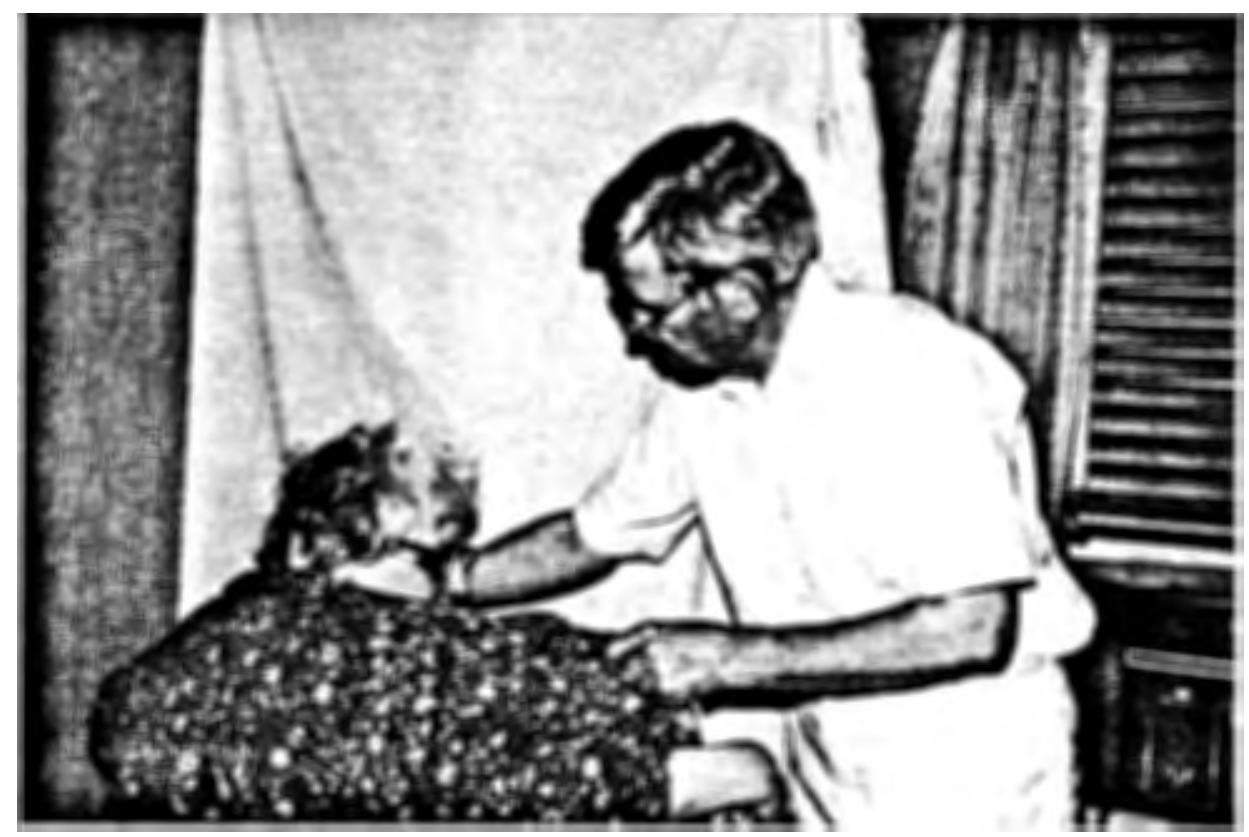

Eigure 13. Male staff--helping to dress.

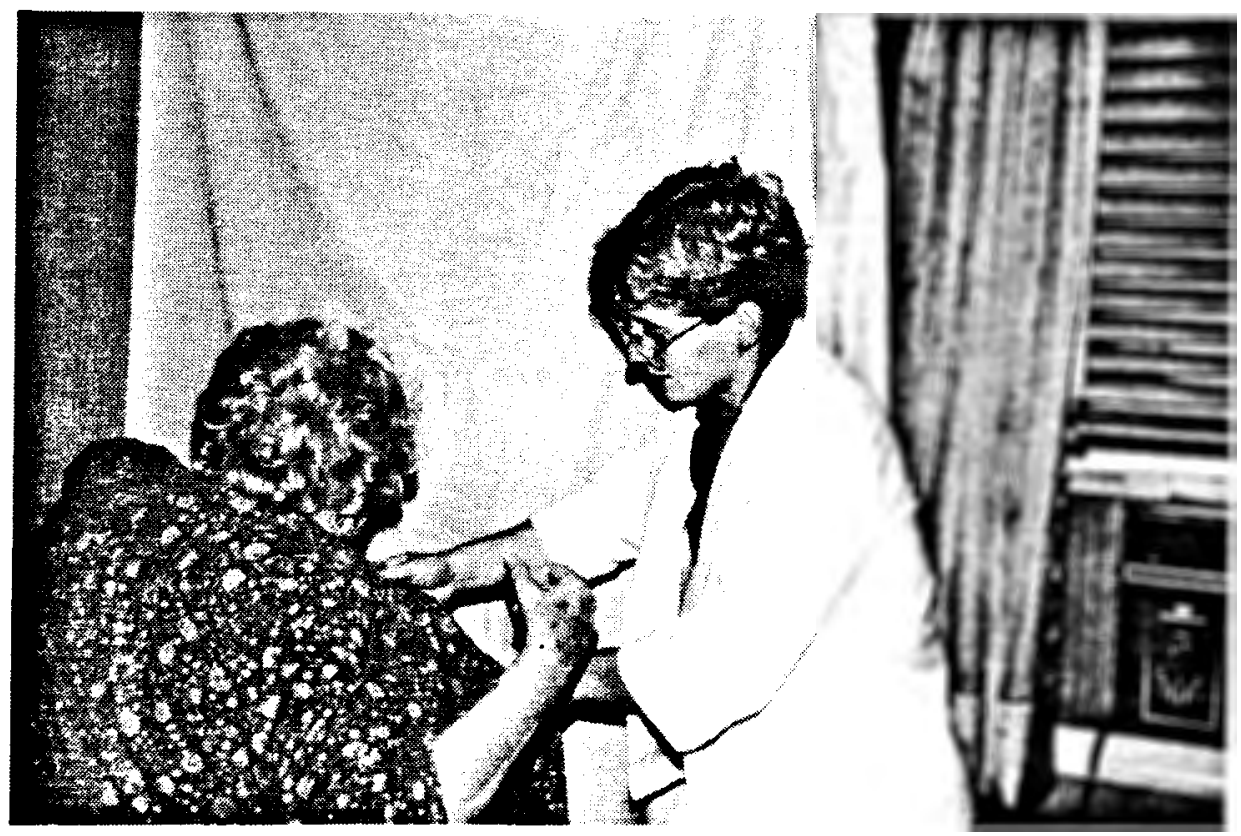

Fiqure 14. Female staff--helping to dress. 


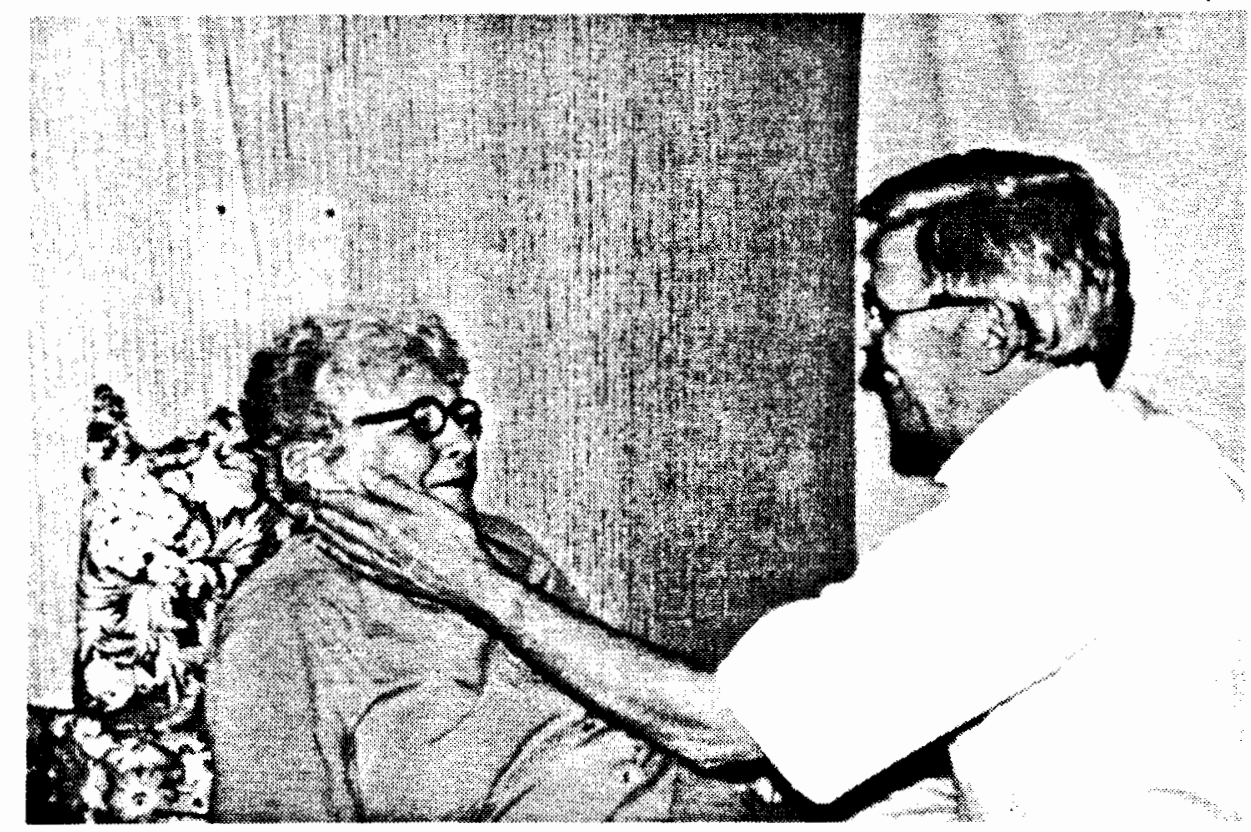

Figure 15. Male staff--stroking cheek.
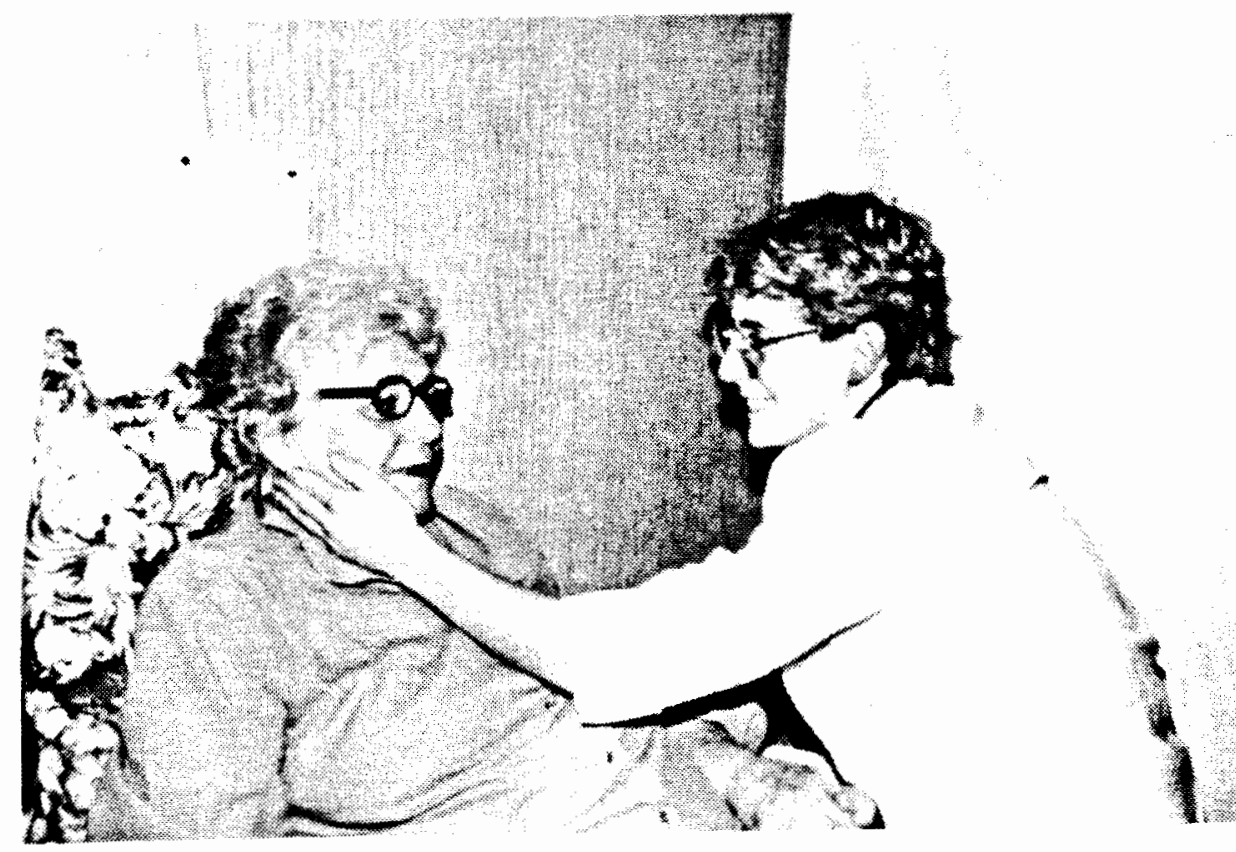

Figure 16. Female staff--stroking cheek. 

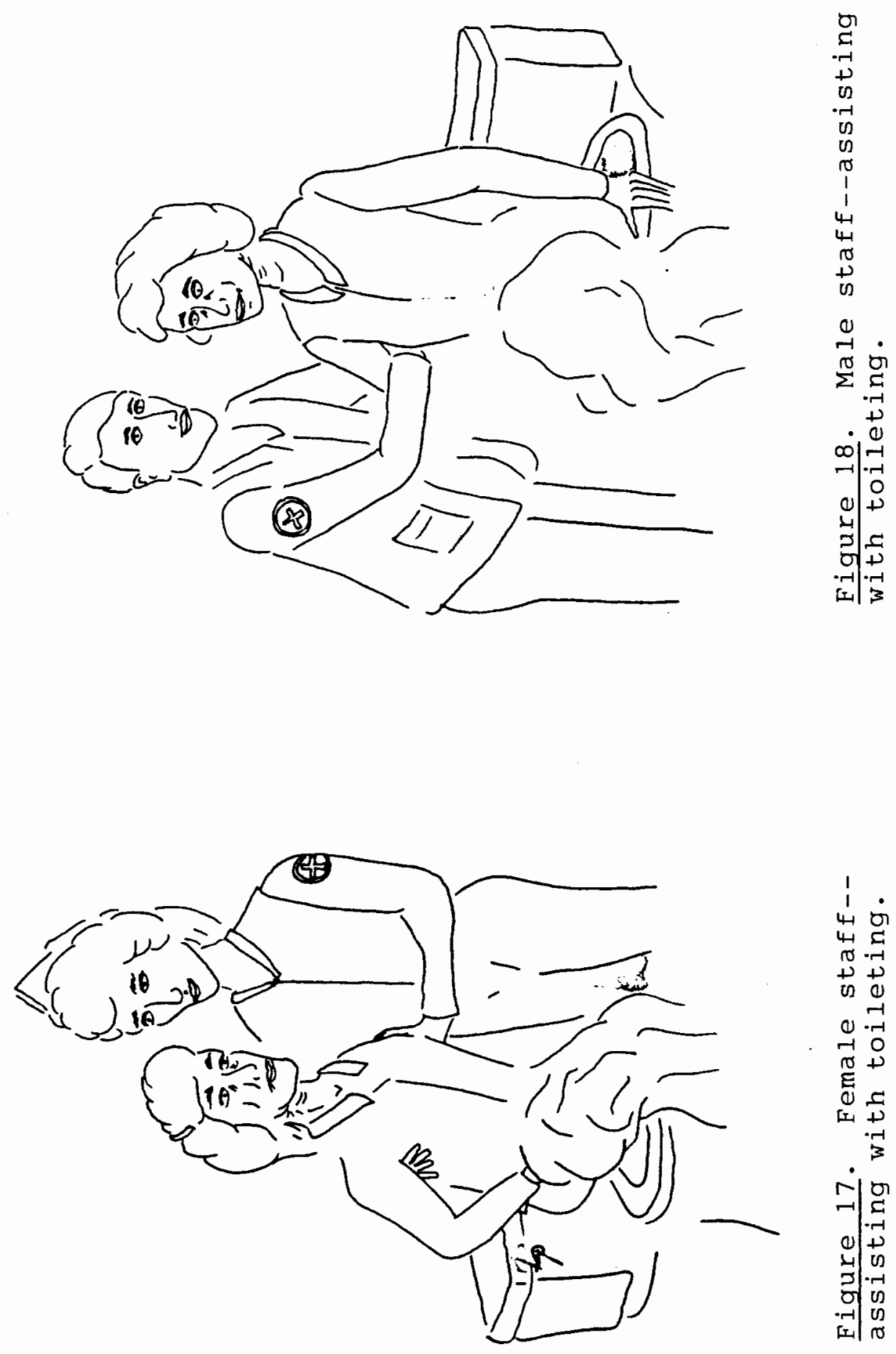

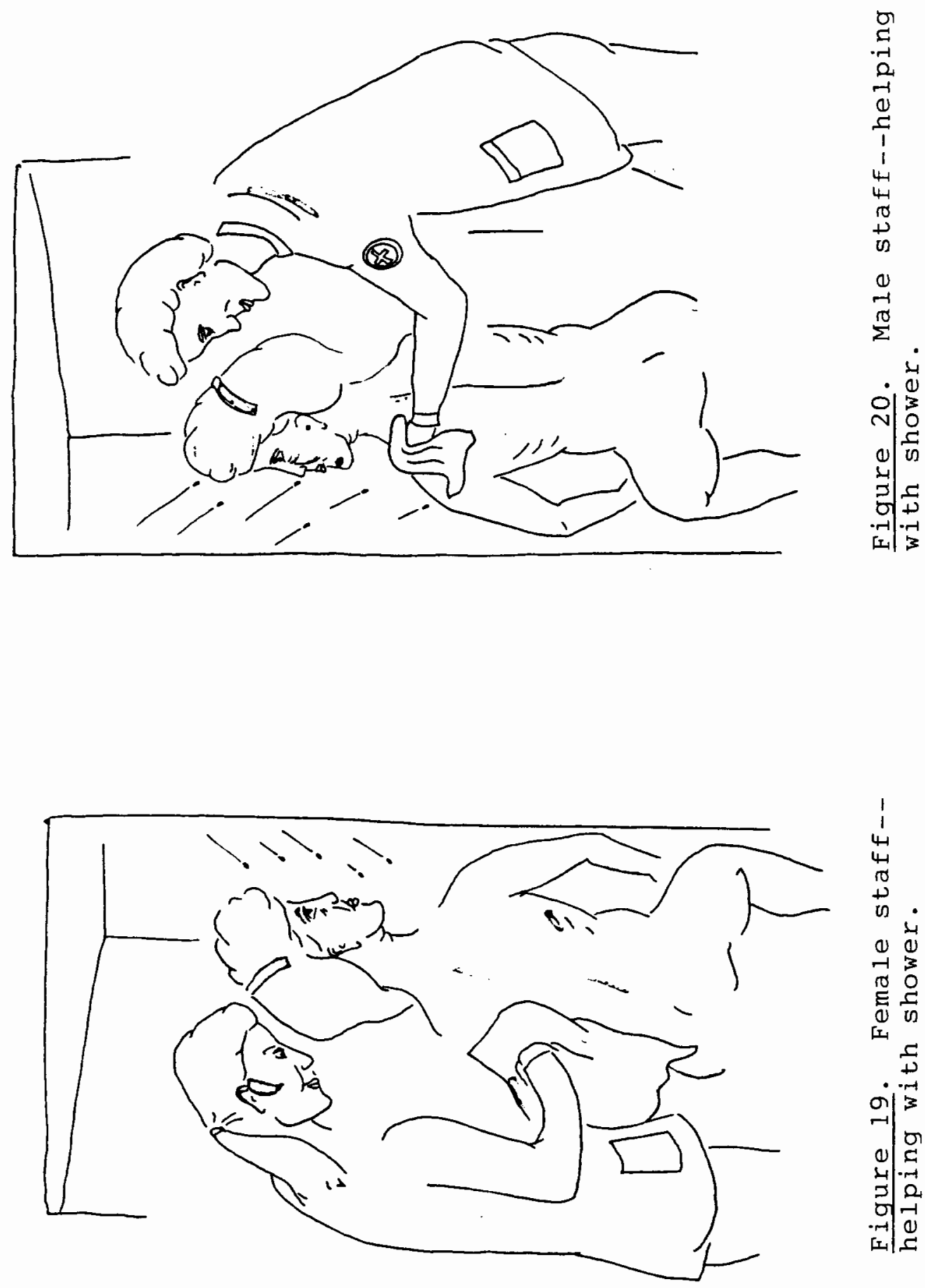

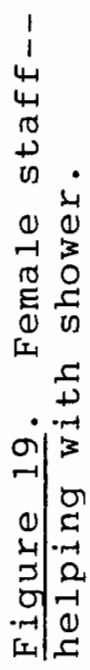


APPENDIX D

RATING CARD

1 Like very much

2 Like

3 Neutral

4 Dislike

5 Dislike very much 
APPENDIX E

RATING FORM

(Name

Number

Interviewer

Date

Like very much

Like

Neutral

Dislike

Dislike very much

1.

2

3

4

5

2.

2

3

4

5

3.

$2 \quad 3$

4

5

4.

2

3

4

5

5.

2

3

$4 \quad 5$

6.

2

7.

2

3

4

5

8.

2

3

4

5

9

2

3

4

5

10.

2

3

11.

2

3

4

5

12 .

2

$13 . \quad 1$

14.

1

2

3

4

5

15.

2

3

4

5

\begin{tabular}{ll}
16. & 1 \\
$17 . \quad 1$ \\
\hline
\end{tabular}

18.

1

2

3

4

5

19.

2

3

$4 \quad 5$

$2 \quad 3$

3

$4 \quad 5$

20.

2

3

4

5




\title{
APPENDIX F
}

\author{
INTERVIEWER INSTRUCTIONS
}

1. Introduce yourself.

2. Explain the purpose of the study: The purpose of this study is to determine how much you like or dislike being touched in different ways by a staff person.

3. Explain that the study will include answering a few questions about themselves, and looking at and rating a set of twenty pictures which demonstrate several ways a staff person might touch them.

4. Ask if the person is willing to participate.

5. Read the informed consent to the participant.

6. Ask for any questions or clarification.

7. Secure the participant's signature, or, if they are willing to participate but reluctant to sign anything, ask a staff person to act as a witness to the person's oral agreement to participate. Retain the signed copy, and leave a copy for the participant.

8. Assign the participant a number and enter the number on both the Demographic Questionnaire and the participant Rating Form.

9. Complete the Demographic Questionnaire.

10. Complete the rating form. Assure the participant that there are no "right" or "wrong" answers. It is their opinion that we seek. After you show two or three of the pictures, you should remind the participant again that the rating is meant to show what they themselves like or dislike in the way of being touched by staff people.

11. Use the bottom of the Demographic Questionnaire form to list any irregularities in the procedure that occur. 
12. Thank the participant for their time, and, if the person would like to visit a little longer, I would encourage you to do so. 


\section{APPENDIX G}

LIST OF PHOTOS AND SKETCHES IN ORDER OF PRESENTATION

1. Male staff--holding hand

2. Male staff--giving back rub

3. Female staff--stroking cheek

4. Male staff--arm around shoulder

5. Female staff--helping to dress

6. Female staff--holding hand

7. Female staff--giving back rub

8. Male staff--helping to stand

9. Female staff--assisting with toileting

10. Male staff--giving foot massage

11. Female staff--brushing hair

12. Male staff--helping with shower

13. Female staff--helping to stand

14. Male staff--stroking cheek

15. Female staff--helping with shower

16. Male staff--brushing hair

17. Male staff--helping to dress

18. Female staff--arm around shoulder

19. Male staff--assisting with toileting

20. Female staff--giving foot massage 
APPENDIX $\mathrm{H}$

INTERVIEWER CHECKLIST

Interviewer Instructions

Informed Consent

Demographic Questionnaire

Set of twenty photos and sketches

List of photo and sketch numbers and titles

Participant Rating Form

Participant Rating card (descriptors for participants) 


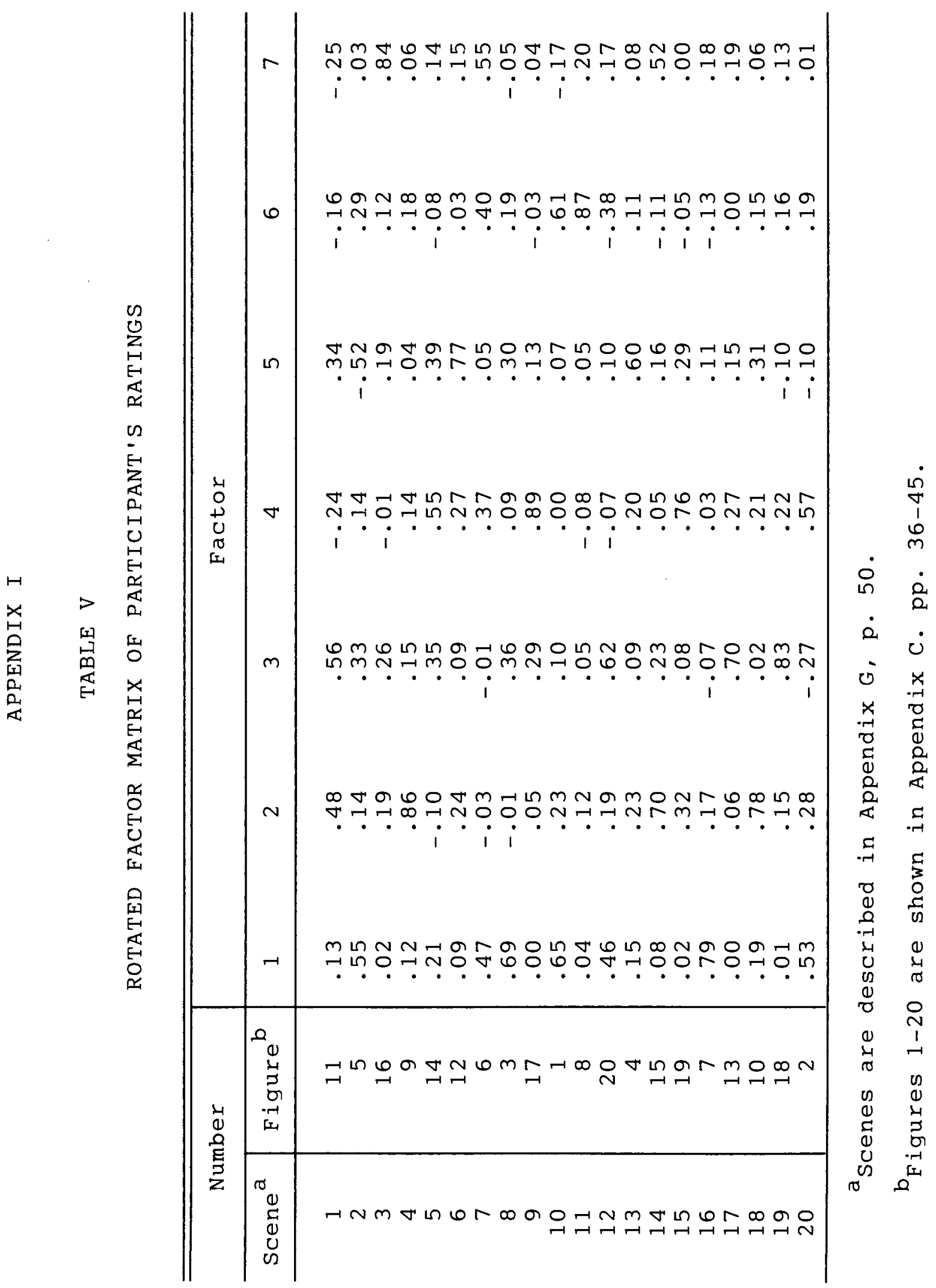

